Review

\title{
Isoflavones in Animals: Metabolism and Effects in Livestock and Occurrence in Feed
}

\author{
Dino Grgic $^{1} \mathbb{D}$, Elisabeth Varga ${ }^{1} \mathbb{D}$, Barbara Novak $^{2} \mathbb{D}$, Anneliese Müller $^{2}$ and $_{\text {Doris Marko }}^{1, *(\mathbb{D})}$ \\ 1 Department of Food Chemistry and Toxicology, Faculty of Chemistry, University of Vienna, Währinger Str. \\ 38-40, 1090 Vienna, Austria; dino.grgic@univie.ac.at (D.G.); elisabeth.varga@univie.ac.at (E.V.) \\ 2 BIOMIN Research Center, Technopark 1,3430 Tulln, Austria; barbara.novak@dsm.com (B.N.); \\ anneliese.mueller@dsm.com (A.M.) \\ * Correspondence: doris.marko@univie.ac.at
}

check for updates

Citation: Grgic, D.; Varga, E.; Novak, B.; Müller, A.; Marko, D. Isoflavones in Animals: Metabolism and Effects in Livestock and Occurrence in Feed. Toxins 2021, 13, 836. https://doi.org/ $10.3390 /$ toxins 13120836

Received: 18 October 2021

Accepted: 19 November 2021

Published: 24 November 2021

Publisher's Note: MDPI stays neutral with regard to jurisdictional claims in published maps and institutional affiliations.

Copyright: (C) 2021 by the authors. Licensee MDPI, Basel, Switzerland. This article is an open access article distributed under the terms and conditions of the Creative Commons Attribution (CC BY) license (https:/ / creativecommons.org/licenses/by/ $4.0 /)$.

\begin{abstract}
Soybeans are a common ingredient of animal feed. They contain isoflavones, which are known to act as phytoestrogens in animals. Isoflavones were described to have beneficial effects on farm animals. However, there are also reports of negative outcomes after the consumption of isoflavones. This review summarizes the current knowledge of metabolization of isoflavones (including the influence of the microbiome, phase I and phase II metabolism), as well as the distribution of isoflavones and their metabolites in tissues. Furthermore, published studies on effects of isoflavones in livestock species (pigs, poultry, ruminants, fish) are reviewed. Moreover, published studies on occurrence of isoflavones in feed materials and co-occurrence with zearalenone are presented and are supplemented with our own survey data.
\end{abstract}

Keywords: isoflavones; genistein; daidzein; glycitein; animal feed; pigs; ruminants; poultry; zearalenone; mycoestrogens; phytoestrogens

Key Contribution: The review provides an overview of the metabolism and effects of isoflavones in livestock. Furthermore, the co-occurrence of isoflavones and zearalenone and its metabolites is summarized and own occurrence data are presented.

\section{Introduction}

Isoflavone(s) (ISF) are secondary plant metabolites belonging to the group of polyphenols [1]. They are characterized by the presence of a benzene ring attached to the third position of the carbon ring [2]. Due to structural and functional similarity with the estrogenactive hormone $17 \beta$-estradiol, ISF are classified as phytoestrogens [3]. ISF (Figure 1) are mainly found in plants of the legumin family and thus, high concentrations occur in soybeans (Glycine max) and red clover (Trifolium pratense). They reside as glycosides with low estrogenic activity compared to their deglycosylated form also referred to as aglycone. Upon ingestion, these compounds are metabolically hydrolyzed by the intestinal microflora to their aglycones thus potentially mediating an estrogenic stimulus [2,4].

Soy products are commonly used as animal feed and due to the increased global production and high protein content of about 38\%, soybeans are the most favored protein provider for pig feed [5]. Soybean-based products contain primarily daidzein (DAI), genistein (GEN) as well as their conjugates and in small amounts glycitein (GLY). The overall ISF content of soybean is $1.2-4.2 \mathrm{~g} / \mathrm{kg}$ dry weight according to older analysis, which agrees with a recent study where the average amount of ISF varies between 0.7 and $5.2 \mathrm{~g} / \mathrm{kg}[6,7]$. In the diet of livestock, besides soybeans also red clover is one of the main sources of ISF. The main ISF in red clover are formononetin and biochanin A [1] and ISF occur in concentrations as high as $10-25 \mathrm{~g} / \mathrm{kg}$ of the dry weight [8] with formononetin accounting for $0.8-11 \mathrm{~g} / \mathrm{kg}$ of the dry weight [9]. ISF concentrations depend on the plant part, growth stage, cultivar, growing conditions, and preservation method $[10,11]$. 
<smiles>O=c1c(-c2ccc(O)cc2)coc2cc(O)cc(O)c12</smiles>

Genistein (GEN)<smiles>O=c1c(-c2ccc(O)cc2)coc2cc(O)ccc12</smiles>

Daidzein (DAI)<smiles>COc1cc2c(=O)c(-c3ccc(O)cc3)coc2cc1O</smiles>

Glycitein (GLY)<smiles>CCOC(=O)OCC</smiles><smiles>COc1ccc(-c2coc3cc(O)cc(O)c3c2=O)cc1</smiles><smiles>CCOC(OCC)c1ccc(-c2coc3cc(O)ccc3c2=O)cc1</smiles>

Figure 1. Structure of various isoflavones and equol, a microbial metabolite of daidzein.

Over the last 50 years, interest in ISF and their effects on animals has increased, especially in the field of agricultural research [12]. Studies have been conducted in various animal species including pigs, cattle, sheep, poultry, and rodents, which found positive as well as negative effects of ISF on the animal health [13-25]. Positive properties that were attributed to ISF are its growth-promoting, antioxidant and antimicrobial effects [26]. However, negative effects of ISF on the reproductive tract were observed in animals, including symptoms such as an enhanced rate of endometriosis, inability to become pregnant and abortions [27]. The first reports of negative effects of ISF on reproductive health date back to the 1940s, when reproductive problems were observed in sheep after excessive consumption of ISF-containing Trifolium subterraneum (subterranean clover), a condition that became known as "clover disease" [28].

In addition to phytoestrogens, other feed contaminants such as mycotoxins possess estrogenic potential. Estrogenic mycotoxins are termed "mycoestrogens". The most prominent examples of mycoestrogens are zearalenone (ZEN) and its derivatives (e.g., $\alpha$-zearalenol, $\beta$-zearalenol, zearalanone, $\alpha$-zearalanol, and $\beta$-zearalanol) (Figure 2$)$. ZEN and its derivatives belong to the group of macrocyclic resorcylic acid lactones and are typically formed by molds of the genus Fusarium (e.g., the species F. graminearum, F. monoliforme and F. culmorum) $[29,30]$. Adverse effects of ZEN in farm animals were extensively described [31-33]. The most frequently described property of ZEN is its estrogenicity. Pigs are most susceptible to those effects [30,34]. In addition, genotoxic, carcinogenic and immunotoxic effects of ZEN were reported [30] Therefore, the European Commission published guidance values for ZEN in feed that amount to 100, 250 and $500 \mu \mathrm{g} / \mathrm{kg}$ for piglets, sows and calves/dairy cattle, respectively $[35,36]$. These values were exceeded in some samples of maize destined to be used as animal feed [37-39].

Since both mycoestrogens and phytoestrogens can occur simultaneously in feed [40], combinatory estrogenic effects might be possible. Vejdovszky et al. showed estrogenic effects of ZEN and GEN depending on the used ratios and concentrations in vitro [41]. However, further data on the combinatory effects of phyto- and mycoestrogens are lacking. 


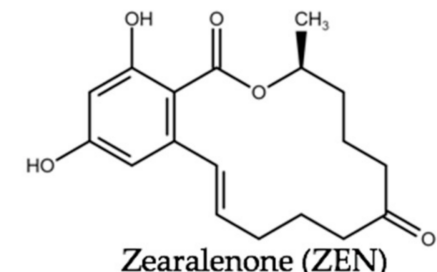
Zearalenone (ZEN)<smiles>C[C@@H]1CC/C=C\C=C\c2cc(O)cc(O)c2C(=O)O[C@H](C)CCC1</smiles>

$\alpha$-Zearalenol ( $\alpha$-ZEL)

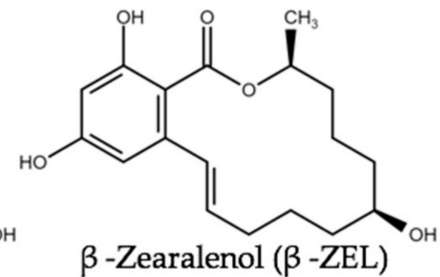

$\beta$-Zearalenol ( $\beta$-ZEL)<smiles>C[C@H]1CCCC(=O)CCCCCc2cc(O)cc(O)c2C(=O)O1</smiles>

Zearalanone (ZAN)<smiles>C[C@H]1CCC[C@H](O)CCCCCc2cc(O)cc(O)c2C(=O)O1</smiles>

$\alpha$-Zearalanol ( $\alpha$-ZAL)<smiles>C[C@H]1CCC[C@@H](O)CCCCCc2cc(O)cc(O)c2C(=O)O1</smiles>

$\beta$-Zearalanol ( $\beta$-ZAL)

Figure 2. Structure of the mycotoxin zearalenone and its phase I metabolites.

This current review summarizes the metabolization of ISF including the influence of the microbiome, phase I and phase II metabolites as well as the distribution and interindividual variability. Furthermore, in vivo studies on effects of ISF in farm animals are reviewed. The focus is on pigs, poultry, and ruminants. In addition, effects in fish are summarized briefly. Furthermore, published data on the occurrence of ISF in feed and co-occurrence with mycoestrogens are presented and supplemented by occurrence data obtained during our own studies.

\section{Metabolism of ISF}

\subsection{Influence of the Microbiota}

The intestinal microbiome plays an important role in the digestion of various food components. Bacteria that colonize the digestive tract are known to modify ISF, which are represented in plants as both glycosides and aglycones. Before ISF can be absorbed from the gut, the sugars of the glycosides must be deconjugated by $\beta$-glucosidases expressed by intestinal bacteria and subsequently, ISF enter the bloodstream via passive absorption [42-44]. Mammalian $\beta$-glucosidase activity does not appear to substantially contribute to deconjugation of ISF glycosides in monogastric animals due to its lower expression level [45].

Apart from the deglycosylation of ISF, further metabolic conversions of ISF are catalyzed by the gut microbiome. In vitro, metabolism of GLY by monogastric fecal flora starts with demethylation to 6-hydroxy-DAI, followed by reduction to 6-hydroxy-dihydro-DAI and subsequent metabolization either by cleavage of the $\mathrm{C}$-ring to $5^{\prime}$-hydroxy-O-demethylangolensin or by maintenance of the C-ring to 6-hydroxy-equol [46].

Biochanin A can be demethylated to GEN by the gut microbiome, both in ruminants and in monogastric animals. GEN is then further processed by the intestinal microflora in different ways depending on the animal species [47,48]. In ruminants, GEN is degraded to $p$-ethyl phenol and organic acids by ring opening [48]. In monogastric animals, GEN is reduced to dihydro-GEN by the intestinal microflora and further metabolized to 6hydroxyif-O-demethyl-angolensin (6-OH-ODMA) [47].

Analogous to biochanin A, formononetin is demethylated to DAI and subsequently reduced to dihydro-DAI (DHD), which is then either degraded by cleavage of the C-ring to $O$-demethyl-angolensin (ODMA) or the formation of equol (EQ) is initiated while retaining the C-ring. This metabolic degradation of DAI is observed in all livestock species [48-50]. However, the capacity of EQ formation varies between the different species. Ruminants possess gut microbiota that favor the biosynthesis of $\mathrm{EQ}$ and therefore all ruminants are 
considered EQ producers [51,52], whereas in pigs the capacity to form EQ is limited and only pigs with certain bacterial strains are classified as EQ producers [53].

The different ability to produce EQ between species is due to the dissimilar composition of the gut microbiota and can also vary with age. The metabolic conversion of DAI to DHD and further to EQ was observed by bacterial strains SNU NiuO16 and SNU Julong732 isolated from bovine rumen [54]. In addition, bacterial strain Slackia sp. D-G6 isolated from chicken intestines was described to produce EQ [55]. Similarly, Eubacterium strains D1 and D2 isolated from pig feces also possess the ability of this metabolic conversion of DAI. However, these isolated strains showed a lower metabolic conversion to EQ than complex mixtures of different fecal bacteria, indicating that other bacterial species are also involved in the formation of EQ [56].

\subsection{Phase I Metabolism}

After absorption, ISF undergo further metabolic processes in the intestine and liver. During phase I metabolism, oxidative modifications by cytochrome P450-dependent monooxygenases (CYP) occur. In vitro, GEN and DAI are converted by rat liver microsomes to different mono-, di-, and trihydroxylated compounds [57]. Biliary and intestinal CYP isozymes (e.g., 1A1, 1A2, 1B1, 2E1 and 3A4) involved in hydroxylation of GEN were already identified in the late 1990s [58]. A similar metabolic pattern was shown for EQ in microsomes of the same species. EQ was metabolized to mono- and dihydroxylated compounds, with 3'- and 8-hydroxyequol being the major products [59]. In a similar experiment, GLY was mainly transformed in rat liver microsomes to two monohydroxylated GLY derivatives and the demethylation product 6-OH-DAI. These results are supported by in vivo studies in rats [46]. In liver microsomes isolated out of sheep and cattle, the conversion of formononetin to DAI was found to be very low. Further conversion to EQ could not be induced by these microsomes [60]. Studies with microsomes of other farm animals are currently unavailable.

The oxidative metabolites of ISF formed in the liver may undergo enterohepatic circulation and therefore, further metabolic conversion by the gut microbiota could be initiated as shown for EQ [61]. Due to their pyrogallol and catechol structure, the oxidative metabolites show a lower stability than their precursors and are therefore difficult to quantify. For humans, it was estimated that less than $10 \%$ of the total ISF content is present as oxidative metabolites in urine [62], whereas bacterial metabolites are of greater importance [63].

\subsection{Phase II Metabolism}

In the further process, ISF are converted to their glucuronides and sulfates in the intestine and liver by means of enzymatic conversion. SULT1A1, among other sulfotransferase (SULT) isoenzymes, is responsible for sulfation, and isoenzymes of uridine diphosphate (UDP)-glucuronosyltransferase (UGT) accomplish the conjugation with glucuronic acid [53]. These conjugation reactions are considered to be the main detoxification pathway for ISF. Cheetahs, for example, which cannot conjugate ISF, showed symptoms of liver damage and infertility after a soy-containing diet [64].

Conjugation occurs mainly at the hydroxy group at C-7 [65-67]. Predominantly monoglucuronides, but also diglucuronides, mono- and disulfates, and sulfoglucuronides were reported [53]. However, the pattern of phase II metabolites differed not only between species, but also between genders. In humans, the main conjugate of phase II metabolism for DAI was the 7-glucuronide-4'-sulfate. For GEN, the metabolites 7-glucuronide- $4^{\prime}$-sulfate as well as the $7,4^{\prime}$-diglucuronide predominate. However, differences between sex were not observed in humans. Rats, on the other hand, showed a divergent phase II metabolite profile between genders. Female rats displayed preferred production of 7-glucuronides for both GEN and DAI. The male counterpart exhibited primarily the production of 7,4'disulfate and 7-glucuronide- $4^{\prime}$-sulfate [68]. A possible explanation for the prioritizing formation of sulfates in male rats can be explained by elevated SULT1A1 mRNA levels [69]. 
Conjugation with sulfates and glucuronic acid occurred predominantly in the liver, but may also involve the gastrointestinal tract [70]. The gastrointestinal epithelium represents an important location for detoxification of phytoestrogens in ruminants. However, there are also differences between species. The conjugation activity of the ISF formononetin, DAI and EQ was up to 20 times higher in sheep compared to cows in almost all parts of the gastrointestinal tract. Among the three ISF mentioned, EQ showed the highest conjugative activity for both species [71].

\subsection{Distribution}

Following absorption and metabolization in both the intestine and liver, ISF are transferred to various body fluids and tissues. These include plasma, urine, feces, and milk on the one hand and kidney, liver, ovary, uterus to name a few on the other hand [53,72-74]. In addition, there is evidence that ISF can cross the blood-brain barrier as well as the placenta $[75,76]$. Depending on the animal species, ISF and their metabolites are present more or less conjugated in plasma and urine. Although in pigs the proportion of aglycones in these fluids is usually less than $5 \%$, the proportion of non-conjugated ISF in urine may be up to $50 \%$ in rats and up to $90 \%$ in monkeys [53]. ISF are also found in tissues in different forms depending on the animal species. For example, in rats the ISF are predominantly present as aglycones, whereas in sheep the vast majority of ISF were detected in conjugated form $[73,77]$.

\subsection{Inter-Individual Variability}

Several different factors may influence biokinetics and bioavailability of ISF such as intestinal microflora, age, composition of feed, and duration of soy consumption. Contradictory data are available on the concentration of EQ in the blood of pigs. Although one study did not detect EQ in the serum of piglets (age 30 days) [53], another study detected EQ in serum of pigs (age 183 days) [78]. This observation might be explained by the different age of the investigated animals. This phenomenon was also observed in rats. Although older rats can produce EQ, no EQ was detected in 3 months old rats [79]. This is attributed to the presence or absence of certain bacterial species that establish itself in the gut in the course of a lifetime [79].

The composition of the feed also seems to have an influence on the metabolism and bioavailability of ISF. It appears that a higher proportion of carbohydrates in the diet and a reduction in fat favors EQ production [80]. Higher levels of carbohydrates may stimulate fermentation in vitro and contribute to increased EQ formation [81]. Likewise, an increase in bioavailability may occur when the feed consists to a minor percentage of oligo-fructose as has been the case in rats for DAI and GEN [82]. In addition, genetic polymorphisms of xenobiotic-metabolizing enzymes such as CYP and UGT may affect bioavailability and metabolism. The genotypes (Val/Leu) and (Leu/Leu) of the gene CYP1B1 are suspected to contribute to an increased risk of breast cancer at a low energy-adjusted daily soy ISF intake [83]. Likewise, the gene polymorphism UGT1a1*28, which is responsible for the conjugation of xenobiotics, has an influence on the metabolic pattern. The presence of this polymorphism in individuals leads to increased excretion of GLY-, DAI-, and GEN-sulfates, causing a decreased production and urinary excretion of glucuronides [84].

\subsection{In Vivo}

\subsubsection{Ruminants}

Compared to monogastric animals, the ruminant's stomach works in a completely different way. Therefore, it is not surprising that also the metabolization of phytoestrogens is different (Figure 3). The rumen is the primary location of the deglycosylation of the ISF glucosides mainly present in the plants, and other transformation processes of the aglycones [48]. Biochanin A is metabolized by demethylation to GEN and further by ring cleavage to para-ethylphenol and organic acids [85]. Formononetin is predominantly demethylated to DAI [85]. EQ is formed from DAI by hydrogenation and ring cleavage. 
Contrary to humans and pigs, ruminants are principally EQ producers [85]. The metabolites formed from biochanin A and GEN are estrogen-inactive substances. Metabolism of formononetin, however, leads to formation of the more estrogenic metabolite EQ [86]. The metabolic processes catalyzed by microorganisms in the rumen may last six to ten days after ingestion [87]. In cows, an ISF-rich diet can play an essential role in their metabolism. One study investigated the degradation of dietary ISF in rumen fluid from cows fed with either a hay diet or a concentrate-rich diet, both including $40 \%$ soybean extract. The results showed faster metabolism of both DAI and GEN under concentrate-rich conditions and an overall higher production of EQ under the hay diet conditions [88]. No significant differences were observed in GLY degradation between the two diet conditions. However, using higher amounts of soybean extracts up to $75 \mathrm{mg}$ per $40 \mathrm{~mL}$ rumen fluid resulted in a decrease in EQ production, most likely because of the inhibitory effects of GEN on the rumen microflora [88]. This decrease is in agreement with a previous study [50]. Only a minimal percentage of hydrolyzed phytoestrogens is absorbed directly from the rumen into the bloodstream [85]. The majority is first subject to further conjugation, predominantly with glucuronic acid [85]. This already takes place in the gastrointestinal epithelium and only a tiny percentage is conjugated in the liver [85]. This fact suggests that in ruminants the liver plays a minor role as an organ for ISF detoxification [85].

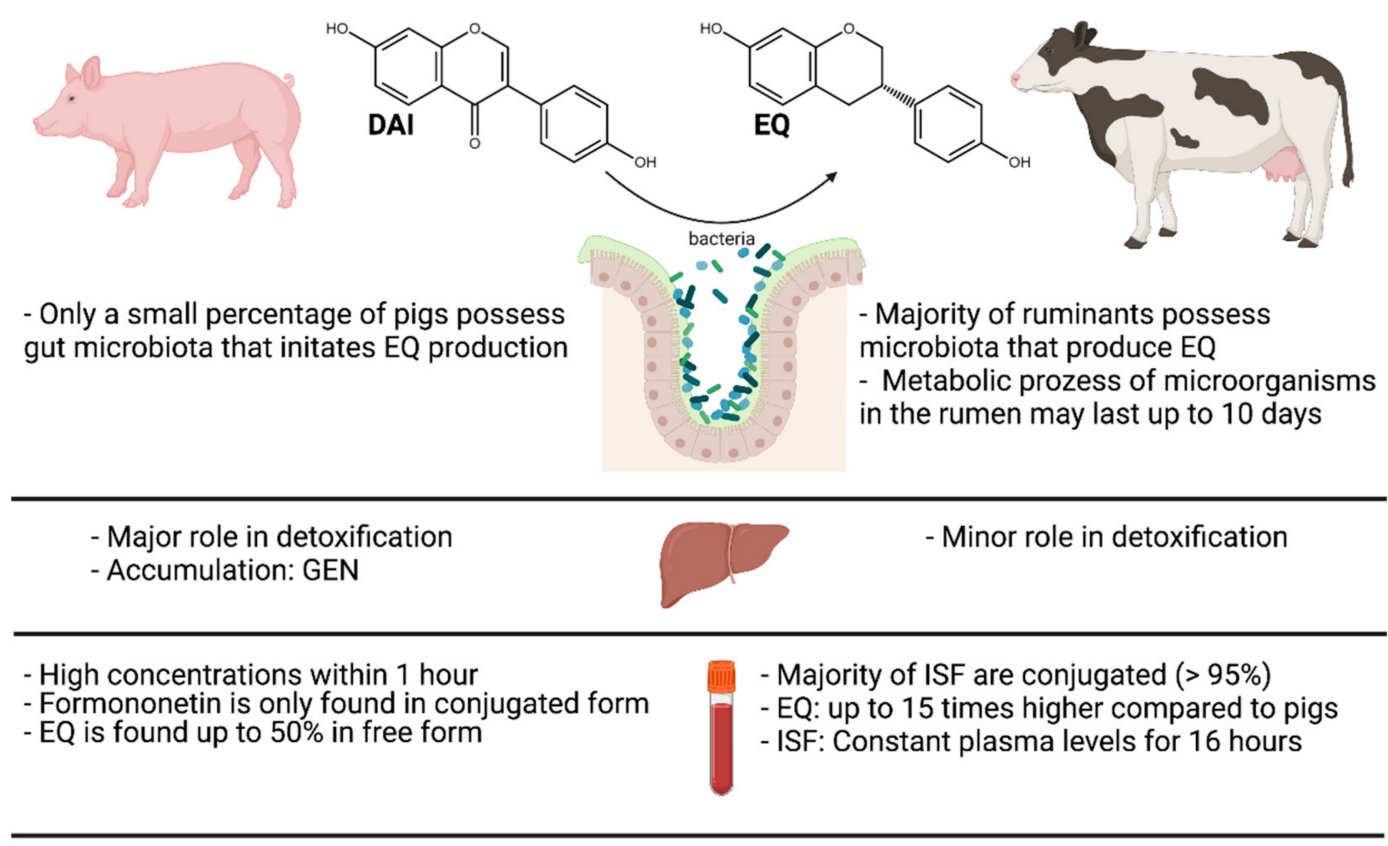

- About $55 \%$ of the ISF are excreted within 8 hours - ISF are excreted mainly unchanged as glucuronides and sulfates

Figure 3. Comparison of the metabolic pattern of ISF between pigs (left) and ruminants (right). ISF = isoflavone(s); DAI = daidzein, $\mathrm{EQ}=$ equol; GEN = genistein. To the best of our knowledge no data are available concerning the excretion of ISF in ruminants. Figure created with BioRender.com.

Feeding trials performed in dairy cattle and ewes revealed that the absorption and distribution of ISF differs within these two species. Formononetin $(530 \mathrm{mg} / \mathrm{kg}$ feed) and DAI ( $12.6 \mathrm{mg} / \mathrm{kg}$ feed) were absorbed very rapidly in dairy cattle, reaching concentrations of about 90 and $50 \mu \mathrm{g} / \mathrm{L}$ in blood plasma, respectively [51]. The concentration of these two ISF was three times higher within the first hour compared to the concentration detected in sheep when fed with the same ISF concentration [51]. The EQ concentration in dairy cows was maintained at a constant level of about $180 \mu \mathrm{g}$ per $100 \mathrm{~mL}$ plasma over a 16-h period. Initially, sheep showed a lower total (free and conjugated) plasma EQ concentration, 
which increased after three hours to the same level as in cows. However, after $16 \mathrm{~h}$, the EQ concentration was half as high as in dairy cows, indicating a faster metabolism of ISF in sheep [51,85]. The amount of unconjugated ISF in the blood was $\leq 5 \%$ for either species, whereby the concentration of free EQ was 10-fold higher in dairy cows compared to ewes at all time points. Nevertheless, sheep are described to be more sensitive to EQ [85]. One of the most plausible explanations is that the estrogen receptors in the uterus are expressed 2-4 times more in sheep than in cows $[89,90]$. Considering that the relative estrogenic potency of EQ is $0.061 \%$ of $17-\beta$-estradiol [91] and that free EQ in sheep can reach concentrations of $20 \mathrm{ng}$ per $100 \mathrm{~mL}$, EQ could reach a 100-fold higher estrogenic potency than 17- $\beta$-estradiol during estrus [92].

\subsubsection{Pigs}

The metabolic profile of ISF in pigs was investigated in a feeding trial with diets containing $20 \%$ red clover with previously determined levels of ISF, corresponding to an average daily intake of $97 \mathrm{mg}$ GEN, $88 \mathrm{mg}$ DAI, $866 \mathrm{mg}$ formononetin and $378 \mathrm{mg}$ biochanin A [85]. Using a permanent vein catheter, the concentrations of the abovementioned ISF could be determined at different time points after feed intake. Within one hour the total (free and conjugated) maximum level of formononetin (100-120 $\mu \mathrm{g} / 100 \mathrm{~mL}$ plasma) was 10 times higher than the level detected in bovine plasma that was also investigated in this study. This observation that formononetin can be detected very rapidly in blood plasma suggests that it is already absorbed to a large extent in the stomach. DAI (5-7 $\mu \mathrm{g} / 100 \mathrm{~mL}$ plasma) and EQ (12-25 $\mu \mathrm{g} / 100 \mathrm{~mL}$ plasma) likewise exhibited the maximum level detected within one hour of feed ingestion, although at 5-15 times lower concentrations compared to formononetin [85]. Other feeding trials have shown that depending on the feed composition, different ISF are primarily detectable in plasma. Measurements after feeding of a soybean meal (SBM) on the one hand and soy protein concentrate (SPC) on the other hand showed that after hydrolytic cleavage of phase II metabolites such as glucuronides and sulfates of ISF, DAI and GEN were detected in higher amounts in the plasma of SBM fed animals [93].

Formononetin was almost exclusively found in the conjugated form, whereas EQ was found up to $50 \%$ in free form in plasma [85]. However, the total amount of EQ in pigs is up to 15 times lower compared to other species such as ruminants [85]. The different ability to produce EQ between species is largely due to the different composition of the gut microbiota. Thus, it appears that pigs in comparison to ruminants possess only a small percentage of the gut microbiota that initiates the conversion to EQ [53]. However, the fact that EQ is detectable in blood and tissues of pigs strongly suggests that pigs are also EQ producers [78,93]. Although Lundh et al. found EQ as a major metabolite of soybean and red clover ISF in pig plasma, Gu et al. detected no EQ in pig serum [53,85]. The difference between these observations might be due to the age difference. In young piglets the intestinal microflora might not be developed sufficiently to produce EQ.

The major metabolites recovered in mammary tissue of pigs were DAI and EQ [78]. These two ISF exhibit estrogenic activity, and both may accumulate in tissues of the reproductive tract and thus strongly affect the reproductive system in pigs [78]. In contrast to DAI and EQ, GEN was mainly detected in the liver of pigs [78]. After absorption, ISF are converted to their glucuronides and sulfates in the intestine and liver by enzymatic conversion [53]. Sulfate conjugates are thought to have a higher estrogenic potential compared to glucuronides [94,95].

About $55 \%$ of the ISF were excreted via urine within the first $8 \mathrm{~h}$ after feed intake [85]. In the case of formononetin, $72 \%$ was excreted via urine without metabolic changes [85]. GEN was also excreted mainly unchanged via urine and only to a minor percentage the metabolite dihydro-GEN was detected [53]. In addition to DAI as the main component of urinary excretion, the metabolites $O$-demethyl-angolensin (ODMA), EQ, and DHD were determined [53]. 


\subsubsection{Poultry}

Several in vitro and in vivo studies on the effects of ISF have been conducted in poultry, especially chickens. Soybean ISF constitute a large part of their diet, and these phytoestrogens transfer to and accumulate in the tissues and eggs of hens $[96,97]$.

In 2001, an experiment conducted at the Tokyo University of Agriculture revealed the transfer of soy ISF to the plasma and egg yolk of laying hens. A group of 5 laying hens was fed a high dietary concentration of soy ISF extracted from soybean hypocotyls over an 18-day period. The concentration of ISF in the ISF-enriched diet was at least 3 times higher than the normal diet, containing for the enriched diet $353 \mathrm{mg} / \mathrm{kg}, 26.2 \mathrm{mg} / \mathrm{kg}$ and $476.9 \mathrm{mg} / \mathrm{kg}$ of DAI, GLY, and GEN, respectively. Analytical data showed a sharp increase in the concentrations of total ISF in plasma and egg yolk until day 12 of feeding with values of $3.2 \mathrm{nmol} / \mathrm{L}$ in plasma and $65.3 \mu \mathrm{g} / 100 \mathrm{~g}$ in egg yolk [96]. Another study reported the transformation of DAI to EQ which then accumulated in the egg yolk of laying hens. The results showed that although most of the ISF (DAI, GLY, GEN) were present in blood and yolk, the concentration of EQ was much higher than the concentrations of other ISF, especially in the egg yolk [97].

\section{Effects of ISF}

\subsection{Ruminants}

Several studies have been conducted in ruminants such as cows and sheep reporting both positive and negative effects on the health of these animals. Several studies revealed the excretion of ingested ISF in ruminant's milk and tissues, as well as increased growth and reduced fertility upon ISF exposure [21-24].

A study investigated the effects of ISF-enriched feed on the carry-over of ISF to milk and on the rumen microbiota in lactating Czech Fleckvieh $x$ Holstein cows. The experimental group received a basal diet supplemented with $40 \%$ more soybean ISF extract $(16,006 \mathrm{mg} /$ day) compared to the control group ( $8401 \mathrm{mg} /$ day). As a result, the concentration of EQ in milk was nearly 2.5 times higher in the experimental group. Additionally, the experimental cows had a reduction in microbial richness compared to control cows [22]. Interestingly, several publications report a high concentration of EQ in bovine milk. A study in Denmark reported a very high EQ concentration of $230 \mu \mathrm{g} / \mathrm{L}$ in organic milk [98]. An even higher EQ concentration of $293 \mu \mathrm{g} / \mathrm{L}$ was detected in the milk of Australian cows that received a high clover diet [99]. Similar to soybean, red clover (Trifolium pretense L.) contains phytoestrogens with the prominent ones being formononetin and biochanin A [100]. It plays a vital role in agricultural processes and has a high crude protein content and fiber, making it an important and feasible option for feeding ruminants. Dairy cows fed with red clover silage have increased milk production as well as higher intake of nutrients compared to animals fed green silage [23,24,101,102]. Similar to the ISF measurements in Australian and Danish bovine milk, two studies performed in France found EQ concentrations of up to $191 \mu \mathrm{g} / \mathrm{L}$ and $1120 \mu \mathrm{g} / \mathrm{L}$ in cow and goat milk, respectively $[103,104]$. Though DAI and GEN were also present in milk, their concentrations were lower compared to EQ concentration $[99,103,104]$. Furthermore, an EQ concentration of $364 \mu \mathrm{g} / \mathrm{L}$ in cows fed with red and white clover silage was also reported [9]. These results are in line with another study where cows were fed with a similar diet $[105,106]$.

The concentration of EQ has been studied not only in milk, but also in meat and tissues [73,107]. In ewes fed a diet of red clover, EQ and DAI found as glucuronides reached high concentrations in plasma. However, these compounds were not equally distributed in different tissues with the highest amount found in the kidney [73]. Lambs fed with red clover pastures showed higher weight gain and fiber intake compared to those receiving a ISF free diet $[19,20,108]$. These observations were in line with another study where red clover-fed lambs had gained more weight than those fed a white clover pasture [109]. Another supporting trial also reported faster growth rates of lambs fed with red clover silage [110]. 
Though phytoestrogens can have a positive effect on milk production of cattle, they can also lead to adverse effects on the reproductive system of both cows and sheep. Several studies have been carried out to test the effects of ISF on the reproduction rate and reproductive tract of the animals, and varying results have been observed in both species [87]. A series of pathological examinations in animals fed mainly with red clover showed signs of cervicitis and hyperplasia in the endometrium of sheep [87]. Chronic infertility was observed in sheep after continuous exposure to ISF, reflected by symptoms that included irreversible changes in estrogen-sensitive organs and completely masculinized ewes [87]. In cattle, only temporary infertility has been observed so far due to ISF exposure. This is reflected by a reduced conception and ovulation rate [87]. In addition, other symptoms such as irregular estrus cycles, vulvar swelling, cyst formation and behavioral abnormalities such as absence of estrus and nymphomania were reported [87]. After discontinuation of ISF exposure, symptoms decreased over a few days to weeks and disappeared with time [87]. Cattle are less sensitive to exposure to ISF compared to other ruminants and this is suspected to be due to differences in estrogen receptors and tremendous weight differences [51]. Formononetin and DAI, which are converted in the rumen into the highly estrogenic EQ, are mainly responsible for infertility [111]. Only three out of five cows fed a soybean-rich diet became pregnant after successful insemination, compared to four out of five cows in the control group [112]. Furthermore, in the same study, cows that received a soybean-rich diet showed elevated levels of prostaglandin $F_{2 \alpha}$ in the blood that were positively correlated with EQ concentrations. The ISF GEN and biochanin A have also been associated with infertility [113]. In one case study, a red clover silage diet caused vaginal discharge and irregular estrous cycles leading to higher miscarriages and premature conception rates in cows [114]. These changes were reversible when feeding of red clover was discontinued [114]. In agreement with these observations, other studies reported the onset of vaginal prolapses, infertility, increased udder size and growth of ovarian cysts in cows fed with red or subterranean clover [115]. Furthermore, cows that received a soy-containing diet showed a lower pregnancy rate and needed a higher number of artificial inseminations than cows that received soy-free diet [112]. In contrast, one study described increased fertility of heifers fed red clover silage [116]. In this study, the heifers were fed either red clover or grass silage prior to and during the insemination period. Cows that received the red clover silage diet showed a significantly higher pregnancy rate to first service, with an increase of 33\% [116].

Infertility of sheep fed with a clover diet gave rise to the so-called "clover disease" [28]. The disease can be classified according to certain clinical conditions such as infertility in ewes that goes hand in hand with changes in the endometrium, prolapse of uterus in unmated ewes and the death of lambs during delivery due to failure of the cervix to dilate properly, mammary development and lactation in unmated ewes and wethers (castrated male sheep), blockage of urethra and death in wethers [21]. Furthermore, sheep that were fed a clover-rich diet showed a loss and or reduction in reproduction [117]. The effects of ISF can cause two different types of infertility problems in sheep, either homeostatic reproduction was recovered after the absence of clover diet or infertility worsening with continued clover-feeding [21]. Indefinite and irreversible infertility in ewes is characterized by a decrease in pregnancy rates, secretory function changes of the cervix and loss of the mucous membrane $[21,118,119]$. Late pregnant ewes that received clover silage from two months prepartum until estrus induction showed a higher interval to estrus, shorter estrus duration and tended to show a decreased litter size compared to ewes that received maize silage [120]. Red clover silage with a high phytoestrogen content fed to nulliparous ewes before, during and after the breeding season did not reduce fecundity compared to a control group that received timothy/meadow fescue grass silage. However, the volume of fetal fluids increased in ewes that received red clover silage, which could increase the risk of vaginal prolapse before the term [121].

In Sweden, a study investigating the effects of dietary phytoestrogens on plasma testosterone and triiodothyronine (T3) levels in male goats was conducted [122]. From 
3 months of age to 6 months of age, the goats received either a basal diet or a diet rich in phytoestrogens. In the first 7 weeks, no significant difference in the concentration of plasma testosterone was observed between the two groups. By the fifth month, the goats fed the ISF-rich diet showed significantly higher testosterone concentrations compared to the control animals. Additionally, the concentration of free T3 was also higher in animals that received ISF-rich feed. These findings suggest that ISF can promote testosterone synthesis during the puberty stage of male goats by increasing secretion of T3 [122].

Concluding, in ruminants, different effects of ISF were reported depending on the animal species and the study design. Cows displayed an increase in metabolism and milk production when they received ISF-rich feed. Animals fed clover silage especially showed increased milk production and nutrient intake [23,88,101,102]. A high concentration of EQ, DAI, and GEN was found in the milk of cows, as well as EQ and DAI in the plasma, meat, and tissue of sheep $[73,105,107,123]$. Similar to cows, lambs fed with red clover pastures (ISF-rich diet) reported higher weight gain and fiber intake, contributing to a faster growth rate of these animals [109]. Unlike poultry, ISF led to an adverse effect on the reproductive system of ruminants, where they caused either a temporary or permanent form of infertility in sheep. The effects of ISF on the reproduction and fertility rate of cows was not as profound, with a few reported miscarriages and infertility which was reversible $[51,87]$. Additionally, in male goats, ISF promoted the onset of puberty by increasing testosterone synthesis [122]. Since soy is one of the most widely used protein sources, an adverse effect on the reproductive system due to the high content of ISF cannot be excluded. In fact, an influence of soy-rich diets on female reproductivity in cows can be observed.

\subsection{Pigs}

Phytoestrogens may affect the growth, meat quality, and immune response system of pigs and are therefore of great interest for the swine agriculture industry. There are several studies on the effect of soybean meal on the growth, intestinal morphology, and antioxidative properties in pigs and piglets. In one experiment, groups of piglets were fed different types of feed, i.e., corn-soybean meal (C-SBM), corn-soy protein concentrate (low ISF C-SPC) or C-SPC enriched with the same ISF concentration as in C-SBM over a period of 72 days [25]. Piglets fed the C-SBM and C-SPC + ISF diets showed higher body weight and greater villus height on day 72 than piglets that received C-SPC feed. In comparison to the C-SPC diet, the pigs fed with dietary C-SPC + ISF displayed an increase in plasma superoxide dismutase (SOD) activity on days 28 and 42 . This was also followed by a reduction in plasma malondialdehyde content on day 42 . In conclusion, the feeding of soybean ISF over a long period of time improved growth performance and antioxidative activity, as well as protection of the intestinal morphology [25]. Lipopolysaccharide (LPS)induced retardation in growth performance, diarrhea, and high plasma concentrations of endotoxins and malondialdehyde have been reversed by supplementation with ISF [124]. Furthermore, LPS challenge significantly increased the abundance of p-p38 and TRL4 proteins in the jejunal mucosa of piglets which are thought to be involved in intestinal damage. The addition of ISF resulted in a decrease of these proteins [124]. A case study determining the effects of dietary soy ISF on growth, carcass traits and meat quality in nearly fully grown pigs was performed [125]. Pigs were allocated to three different diets: (1) C-SBM; (2) C-SPC or (3) C-SPC + ISF. Pigs fed the C-SPC + ISF diet showed an increase in carcass length, percentage ham lean and thaw loss, combined with an overall reduction in total ham fat [125]. Pregnant sows that received dietary DAI and GLY from day 85 of gestation littered piglets with higher birth weight and average daily gain $[18,126]$. However, the effect of ISF on growth performance is contradictory in the literature. In a study by Xiao and coworkers, piglets that received a dietary DAI level of $400 \mathrm{mg} / \mathrm{kg}$ showed lower average daily weight gain than the control group that did not receive DAI [15]. The discrepancy between the observed effects of ISF on growth performance may be due to differences in age of the animals, duration of the study or the kind and dose of 
ISF. Furthermore, such high DAI concentration had a trend to cause mild damage of the kidneys, livers and spleens of the weanling pigs after 70 days [15].

Several studies have reported beneficial effects of ISF in pigs challenged with viral infections. One study investigated the effects of dietary SBM infused with ISF on the growth performance and immune response of pigs inoculated and infected with porcine reproductive and respiratory syndrome virus (PRRSV). The effect of ISF enhanced immune response by reduced concentrations of serum viral load and improved growth [127]. This agreed with another study about the effects of dietary soy ISF on the response of weanling pigs to PRRSV. The ISF supplemented to the pigs reduced PRRSV-induced circulating neutrophils and improved the cytotoxic-to-helper T-cell ratios [128]. The findings suggest that ISF contribute to activating the adaptive immune system and in clearance of viral infections [128]. Furthermore, the effect of dietary soy GEN on pig growth and viral replication was also investigated. Increasing concentrations of dietary GEN were associated with a decrease in serum content of the PRRS virus and a quadratic increase in daily feed intake [129]. Furthermore, a study by Smith and coworkers found that dietary ISF reduced the mortality of pigs challenged with PRRSV [130].

One study investigated the effects of a high DAI dose $(640 \mathrm{mg} / \mathrm{kg}$ feed $)$ on the redox system in tissues of finishing pigs over a period of 64 days [16]. On the one hand, the supplemented high dosage increased SOD activity and total antioxidant capacity in the longissimus muscle of the animals, and it reduced activity of NADPH oxidase-2 and cyclooxygenase-2, enzymes involved in the production of reactive oxygen species. However, on the other hand, it also induced pro-oxidant changes in back and abdominal fat, liver, and plasma tissues by promoting the expression of reactive oxygen species producing enzymes. To conclude, finishing pigs fed with high doses of DAI show improved redox activity in muscle and, in contrast, increased oxidation levels in liver and fat tissues [16]. Similar to its precursor DAI, the metabolite EQ also displays antioxidant effects in piglets. A case study reported that lactulose increased EQ production and improved liver antioxidant status in barrows supplemented with DAI [131]. After 20 days, EQ concentrations were significantly elevated in both urine and fecal samples. Additionally, the activity of the enzymes SOD and copper-zinc SOD increased in the livers of barrows, thus improving the overall antioxidant characteristics of the animals [131].

The effects of ISF on the reproductive system of pigs have also been studied, though not as much as in sheep and cattle. A study from China investigated the effects of soybean ISF on male reproductive parameters using Chinese mini-pig boars as a model [132]. Dietary concentrations of soybean ISF of 0 to $500 \mathrm{mg} / \mathrm{kg}$ were administered to the pigs for 60 days. An ISF concentration of $250 \mathrm{mg} / \mathrm{kg}$ increased the testis index, fructose content in testicular tissue, alpha-glycosidase content in testicular tissue, as well as viable germ cells and level of apoptosis regulating Bcl-2 protein in testicular tissue. Pigs fed $500 \mathrm{mg} / \mathrm{kg}$ of soybean ISF exhibited a significant decrease in testis and epididymis indexes and serum testosterone levels, as well as an increase in numbers of early and late apoptotic germ cells and level of pro-apoptotic BAX proteins in the testis. In conclusion, low to moderate consumption of soybean ISF did not affect reproductive parameters in the mini-pig board, whereas higher concentrations negatively affected male reproductive health [132].

Similar to the Chinese mini-pig boars, another study also investigated the effects of soybean ISF on the onset of puberty, serum hormone concentration, and gene expression in hypothalamus, pituitary gland and ovary of female Bama miniature pigs [133]. The pigs received dietary soybean ISF doses between 0 and $1250 \mathrm{mg} / \mathrm{kg}$. Compared to the control group, the pigs fed $1250 \mathrm{mg} / \mathrm{kg}$ soybean ISF exhibited a significant delay in the onset of puberty. At 4 months of age, a reduction in serum concentration was observed for gonadotrophin releasing hormone and luteinizing hormone, whereas the serum concentration of follicle-stimulating hormone increased. The soybean ISF-supplemented pigs also showed a reduction in ovary of steroidogenic acute regulatory protein and KiSS-1 metastasis-suppressor. To conclude, soybean ISF adversely affected the reproduction sys- 
tem in female pigs by delaying the onset of puberty due to the decreased expression in reproduction-regulating genes [133].

Feeding red clover silage to pigs induced signs of hyperestrogenism such as fertility problems [85]. Further feeding trials of 10- to 24-week-old piglets with soy showed that the soy-containing diet induced estrogenic effects in the piglets [134]. Again, symptoms of hyperestrogenism such as swelling of the mammary gland and vulva, enlargement of the uterus, and pathological changes of ovaries were observed. These data also suggest that with continuous feeding of soy, the vulva size increased with each week. This observation implies that there is an enhanced estrogenic effect over time due to cumulative effects [134].

Ovariectomized gilts are often used as a model to study estrogenic properties of different substances. Because they have a deficit in estrogens, the effect of mildly estrogenic substances can be determined. Therefore, Ford and coworkers [135] studied the effect of GEN in ovariectomized gilts. The gilts received daily intramuscular injections of 50-400 mg GEN. Doses of $\geq 200 \mathrm{mg}$ caused a significant increase in cervix and uterine mass.

DAI exposure of pregnant sows caused swelling and reddening of the vulva in neonatal piglets [136]. Compared to the control group, the male newborn piglets whose mothers were fed with DAI had a significantly higher birth weight. No other influences on the piglets were observed. However, the addition of GEN and DAI to the feed of lactating sows caused estrogenic effects in the piglets, which are most susceptible to exogenous endocrine disruptive chemicals (EDC) at this stage of their lives. It can be concluded that ISF exposure through breast milk led to an exposure of the estrogenic substances to the piglets causing hyperestrogenism in female piglets [136].

In conclusion, ISF were shown to exert both positive and negative effects in pigs. Soybean meal improved the growth performance and antioxidative activity in pigs [15,124-126]. In PRRSV-challenged pigs, ISF improved immune functions and reduced mortality $[129,131]$. However, phytoestrogens also showed negative effects. ISF caused hyperestrogenism in female piglets $[85,134]$. Similar to what was observed in sheep, high consumption of soybean ISF negatively affected male reproduction [132]. Furthermore, high doses of ISF were reported to have toxic effects including increased oxidation levels in liver and fat tissues [16] and soybean meal fed pigs showed reduced total ham fat [124].

\subsection{Poultry}

Chicken that were fed with a soy ISF-rich diet (starting at $1000 \mathrm{mg} I S F / \mathrm{kg}$ feed) showed significantly higher plasma levels of estradiol compared to chicken on a basal diet. The same chicken were also much healthier as shown by improved egg and white egg weight over the course of the experimental period of 3 months [17]. The improvement in egg weight is in agreement with increased egg production and quality, as reported in previous studies [96,137]. Studies investigating the effects of soy ISF (DAI, GEN, GLY) on the laying performance of Xueshan breeder hens found that an ISF diet increased yolk color and serum total antioxidant capacity and immune levels [138-140]. Furthermore, ISF caused an increase in hatching rate potential of 36-weeks old hens [138]. However, ISF caused a reduction in average egg weight in 52-weeks old hens and a decrease in egg rate in 44-weeks old hens [138]. Dietary administration of DAI to laying hens at doses of 10, 100 or $200 \mathrm{mg} / \mathrm{kg}$ for 12 weeks increased hatchability [139]. Furthermore, dietary DAI doses of 10,20 and $30 \mathrm{mg} / \mathrm{kg}$ showed a positive effect on egg weight and fertility in Zhedong white geese [141].

$\mathrm{Ni}$ and coworkers investigated the effect of DAI on the egg-laying performance in Shaoxing duck breeders [137]. The following criteria were measured: egg-laying rate, egg composition, feed conversion ratio, hatchability characteristics of eggs and body weight, ovary and oviduct weight, and changes in serum concentrations. Doses of $3 \mathrm{mg} / \mathrm{kg}$ and $5 \mathrm{mg} / \mathrm{kg}$ DAI administered to ducks over 35 days resulted in an increase in the egglaying rate, mean egg weight, and feed conversion ratio. However, a negative effect on fertility and hatchability responses was observed. Extending the feeding period to 63 days caused a $7.7 \%$ increase in the egg-laying rate, as well as higher body and oviduct weight. 
Additionally, the yolk and albumen ratio were reduced. This suggested that DAI has ambiguous effects on the laying performance of the ducks depending on the physiological conditions and DAI dose [142]. The impact on the laying rate seems to depend on the age of poultry. In 7-months old female quails, supplementation of $6 \mathrm{mg} / \mathrm{kg}$ DAI led to a decrease in laying rate, whereas the same amount of DAI led to an increase in laying rate in 12 months old quails [13].

Different effects have been observed in Japanese quails. In one study, ISF administered to female quails via the diet did not affect growth, feed intake or weight of oviduct [14]. Likewise, ISF did not affect growth or feed intake in male quails in the same study. However, the same male quails exhibited a $40 \%$ reduction in photoperiod-induced testis development suggesting ISF negatively affect the reproduction system of male quails [14]. It was reported that the supplementation of GEN in Japanese quail suppressed spontaneous oviduct tumorigenesis. The results indicated that GEN supplementation significantly reduced the occurrence and size of spontaneously occurring leiomyoma of the oviduct in the quail [143].

In a study in broiler chickens very high dietary concentrations of soy ISF (starting at $693 \mathrm{mg} / \mathrm{kg}$ ) decreased the growth rate [144]. In contrast, the administration of lower ISF concentrations ( 10 and $20 \mathrm{mg} / \mathrm{kg}$ ) increased the weight and feed intake of male broilers compared to the control group [145]. Following, one study could show that supplementation of GEN ( $400 \mathrm{mg} / \mathrm{kg}$ ) fed for 8 weeks significantly improved the reproductive activity and bone status of laying broiler breeder hens. The GEN-rich diet induced an increase in the levels of vitellogenin, progesterone, and follicle-stimulating hormone in the serum [146]. In addition, the levels of malonaldehyde in the follicle and egg yolk of hens decreased, while calcium and phosphorus levels increased in the tibia, which explains the improved strength of tibia bone [146].

Antioxidant effects of ISF have also been observed in poultry. One study highlighted the positive benefits of an ISF-rich diet on broiler chickens suffering from the infectious bursal disease virus (IBDV). Dietary ISF improved the overall health and condition of infected chickens. This effect was attributed to the decreased expression of viral protein 5 mRNA, a protein produced in response to IBDV to drive apoptosis [147,148]. ISF also decreased the onset of bursa lesions and additionally had a high antioxidant capacity [147]. Further antioxidative properties of ISF in male broiler are described by the consumption of 40 or $80 \mathrm{mg}$ ISF per kg bodyweight, which leads to an increased antioxidant capability and superoxide dismutase activity in plasma [145].

To conclude, in poultry, high ISF concentrations in the diet increased the rate of egg production and hatching rate due to increased estrogen activity and weight in some studies $[138,149]$. However, ISF decreased average egg weight in 52-weeks old laying hens and egg rate in 44-weeks old laying hens [138]. High ISF concentrations were linked to improved antioxidant effects and immune system as well as a reduction in blood cholesterol levels, improving overall health, and such rich diets decreased the onset of bursa lesions and viral mRNA in chickens infected with infectious bursal disease virus (IBDV) $[140,147,150]$. Additionally, the ISF GEN affected the reproductive system and bone status of hens and ducks, by capacitating their performance and enhanced strength of their tibia bone [146]. Several negative effects of ISF were observed in quails. Dietary ISF caused a decrease in the laying rate of 7-months old female quails [13] and negatively affected the development of the reproductive tract in males [14].

\subsection{Fish}

Studies about the effects and the metabolic fate of ISF on aquatic species are scarce. However, one research team showed that the supplementation of soy ISF to the diet of the marine fish "golden pompano" caused an increased growth rate [151]. In contrast, higher levels of ISF supplementation in diets of some other fish species such as Japanese flounder, Atlantic salmon fry and yellow perch led to a significant reduction in the weight of the animals [152-154]. Therefore, a general conclusion is not possible and in other marine species, such as striped bass fingerlings, no effect of ISF on the growth was observed [155]. 
These differences in the effect of ISF-supplemented diets may be due to different ISF pattern or might be species dependent. ISF supplementation is known to alter the digestive process by inducing a reduction in maltase activity, which is a key enzyme in the digestion of carbohydrates in fish [154]. In addition, a tendency towards skeletal malformation was observed in ISF-fed Atlantic salmon presumably related to the reduction of thyroid peroxidase [154]. Thyroid peroxidase is mainly involved in the synthesis of thyroid hormone (TH), which in fish plays a crucial role in the development of the musculoskeletal system [156]. Another factor that may contribute to the impaired growth of salmon fry is the depletion of glycogen in hepatocytes induced by ISF-containing diets [154].

Studies indicate that consumption of ISF leads to a decrease in whole body crude lipid content in juvenile Japanese flounder [152]. It was suggested that this decrease is due to an effect of ISF on transcription factors which modulate the expression of genes involved in lipogenesis or lipolysis [157]. Considering that there is little data on the metabolism of ISF in fish, it is also inconclusive whether fish can produce EQ or not. For example, no EQ was detected in the bile of rainbow trout fed with DAI (up to $49 \mathrm{mg} / \mathrm{kg}$ feed) [158], whereas EQ could be detected in the tissue of sturgeons (EQ intake up to $432.3 \mathrm{mg}$ ) [159]. However, it cannot be concluded from these results that sturgeons are in fact EQ producers as EQ was also present in feed. Additionally, the ISF profile detected in the serum indicates that sturgeons did not produce EQ in this experiment [159].

The metabolism of ISF in sturgeons seems to be delayed, as high concentrations were found in the liver (up to $3.5 \mathrm{mg}$ ISF per $\mathrm{kg}$ liver), indicating an accumulation [159]. This accumulation can cause a chronic estrogenic effect in hepatocytes, which is reflected by increased vitellogenin synthesis observed both in vivo and in vitro [160,161]. In Siberian sturgeons, intraperitoneal administration of GEN, EQ, and biochanin A increased vitellogenin levels in blood, thus exerting an estrogenic effect [162]. Therefore, particular attention should be drawn to GEN because of its high occurrence in fish feed and accumulation in tissues, which can result in particularly high estrogenic effects [162]. In rainbow trout, GEN, DAI, and GLY can inhibit the metabolism of E2 in the kidney and liver. Inhibition of E2-metabolizing enzymes may result in increased bioavailability of E2 in peripheral target tissues. This could be another potential mechanism of how ISF induce estrogenic effects [163].

ISF had a positive effect on immune parameters in golden pompano. Feeding 40 $\mathrm{mg} / \mathrm{kg}$ ISF resulted in a significant increase in C3 protein, which is part of the humoral immune response and plays a central role in the lysis of pathogenic cells and bacteria [151]. Moreover, there was an increase in plasma lysozyme activity due to ISF. Lysozyme activity is an important index of innate immunity, which plays a more important role in fish than in mammals. Numerous other immune parameters and health indicators such as increased activity of respiratory bursts, decrease of glutamic-pyruvic transaminase and oxalacetic transaminase and increase of HSP70 were induced by ISF supplementation [151].

\section{Occurrence}

\subsection{Literature}

As pointed out in the introduction, significant concentrations of ISF are mainly found in plants of the Fabaceae family [164]. However, ISF content as well as the overall composition of soybeans and red clover are subject to wide variations depending on cultivar, season, and further processing [165].

In addition to contamination with ISF, contamination of feed and food with zearalenone (ZEN) and its metabolites may occur at different stages of the feed supply chain. ZEN-producing Fusarium species grow well in humid weather on the fruit or stalk of grain and their growth is accelerated by improper storage. Contamination with ZEN and its metabolites is common in commodities such as wheat, corn, rice, barley, soybean. [166-168].

The occurrence of ISF and the incidence of ZEN in a diverse range of feedstuffs analyzed over the last 10 years is provided in Table 1 . Although there are numerous studies regarding the occurrence of ZEN and its metabolites in feed over the last decade, there 
is only scarce data on the incidence of ISF. However, in all samples the detected average concentrations of ISF are in the medium to high $\mathrm{mg} / \mathrm{kg}$ range. In silage samples that are composed of clover, grass, and cocksfoot, the prevalent ISF are formononetin and biochanin A and this in accordance with previous reports [100,169].

The situation is different for soybean meal and cow feed samples, where the glycosides genistin and daidzin are the predominate ISF. Cow feed samples from Thailand reached maximum concentrations of 57 and $42 \mathrm{mg} / \mathrm{kg}$ feed for genistin and daidzin, respectively [40]. The concentrations of these two ISF in soybean meal feed were even higher, reaching 1274 and $785 \mathrm{mg} / \mathrm{kg}$ feed for genistin and daidzin, respectively. No cases were reported where the aglycon showed higher concentrations than its respective glucoside [40]. Compared to the samples from the US, soybean feed samples from Brazil and Argentina had higher concentrations of ISF, which could be due to environmental factors that lead to higher concentrations of ISF in soybean meal [72]. The prevalence of ZEN was in most of the samples very high. Some samples also exceeded the EU guidance values for acceptable ZEN concentrations in pig feed [167] (EU guidance values for: piglets and gilts $0.1 \mathrm{mg} / \mathrm{kg}$; sows and fattening pigs $0.25 \mathrm{mg} / \mathrm{kg}$; calves and dairy cattle $500 \mu \mathrm{g} / \mathrm{kg}$ ). Feed samples were found that exceeded the guidance value for piglets and gilts in every region of the world. For samples from East Asia, $27.3 \%$ of the analyzed samples exceeded the guidance value for piglets and gilts [167].

Among the few studies investigating the co-occurrence of ISF and ZEN or its metabolites in feed, one study from Thailand reported ZEN concentrations of $0.96-55.6 \mu \mathrm{g} / \mathrm{kg}$ in cow feed, and low to middle concentrations of ISF $(0.030-57.9 \mathrm{mg} / \mathrm{kg})$ in cow feed [40]. Additionally, a study published in 2021 showed that ISF co-occurred with ZEN in pasture samples from Austria [170]. 
Table 1. Occurrence data of ISF and ZEN and its metabolites in feed from literature of the last decade.

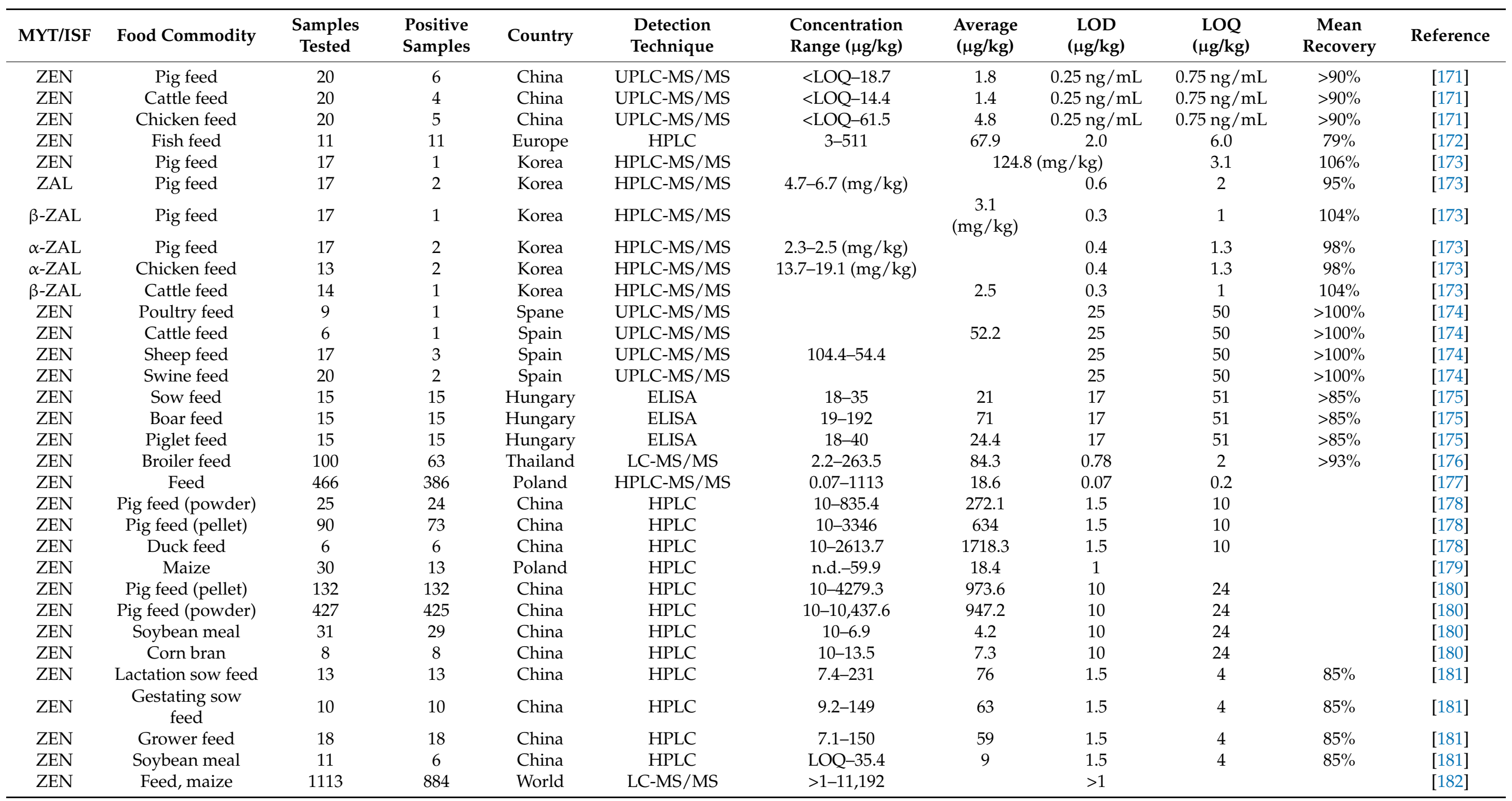


Table 1. Cont

\begin{tabular}{|c|c|c|c|c|c|c|c|c|c|c|c|}
\hline MYT/ISF & Food Commodity & $\begin{array}{l}\text { Samples } \\
\text { Tested }\end{array}$ & $\begin{array}{l}\text { Positive } \\
\text { Samples }\end{array}$ & Country & $\begin{array}{l}\text { Detection } \\
\text { Technique }\end{array}$ & $\begin{array}{l}\text { Concentration } \\
\text { Range }(\mu \mathrm{g} / \mathrm{kg})\end{array}$ & $\begin{array}{c}\text { Average } \\
(\mu \mathrm{g} / \mathrm{kg})\end{array}$ & $\begin{array}{l}\text { LOD } \\
(\mu \mathrm{g} / \mathrm{kg})\end{array}$ & $\begin{array}{c}\text { LOQ } \\
(\mu \mathrm{g} / \mathrm{kg})\end{array}$ & $\begin{array}{c}\text { Mean } \\
\text { Recovery }\end{array}$ & Reference \\
\hline ZEN & Poultry feed & 20 & 17 & Korea & HPLC & $5.2-147.5$ & 35 & 1.3 & 8 & $>75 \%$ & [183] \\
\hline ZEN & Dairy cattle feed & 40 & 24 & $\begin{array}{l}\text { South } \\
\text { Africa }\end{array}$ & LC-QTOF-MS7MS & LOQ-28 & 2.8 & 0.04 & 0.12 & $>150 \%$ & [184] \\
\hline$\alpha-Z E L$ & Dairy cattle feed & 40 & 40 & $\begin{array}{l}\text { South } \\
\text { Africa }\end{array}$ & LC-QTOF-MS7MS & $1-13.2$ & 4.8 & 0.19 & 0.63 & $>99 \%$ & [184] \\
\hline$\beta$-ZEL & Dairy cattle feed & 40 & 40 & $\begin{array}{l}\text { South } \\
\text { Africa }\end{array}$ & LC-QTOF-MS7MS & $0.7-4.7$ & 2.4 & 0.19 & 0.64 & $>99 \%$ & [184] \\
\hline$\alpha-Z E L$ & Animal feed & 77 & 5 & Egypt & LC-MS/MS & LOQ-8 & & 1.3 & 4.5 & $84 \%$ & [186] \\
\hline$\beta$-ZEL & Animal feed & 77 & 28 & Egypt & LC-MS/MS & LOQ-60 & & 1.2 & 3.5 & $87 \%$ & [186] \\
\hline ZEN & Animal feed & 77 & 71 & Egypt & LC-MS/MS & LOQ-791 & & 0.6 & 2.1 & $86 \%$ & [186] \\
\hline ZEN & Finished feed & 146 & 94 & Africa & LC-MS/MS & LOQ-518 & & & & & [187] \\
\hline ZEN & Finished feed & 301 & 173 & $\begin{array}{l}\text { South } \\
\text { Africa }\end{array}$ & LC-MS/MS & LOQ-386 & & & & & [187] \\
\hline ZEN & Soy & 30 & 24 & Brazil & HPLC & LOQ-104 & 16.7 & 2 & 6 & $>99 \%$ & [188] \\
\hline ZEN & Soybean meal & 14 & 10 & Pakistan & HPLC & $0.15-120.9$ & 18.9 & 0.05 & 0.15 & $>85 \%$ & [189] \\
\hline ZEN & Poultry feed & 11 & 9 & Pakistan & HPLC & $0.15-125.2$ & 15.8 & 0.05 & 0.15 & $>85 \%$ & [189] \\
\hline ZEN & Cattle feed & 174 & & Korea & HPLC-MS/MS & & 134.2 & $0.1-3$ & $0.3-8$ & $>96 \%$ & [190] \\
\hline ZEN & Swine feed & 160 & & Korea & HPLC-MS/MS & & 31.7 & $0.1-3$ & $0.3-8$ & $>96 \%$ & [190] \\
\hline ZEN & Poultry feed & 160 & & Korea & HPLC-MS/MS & & 37.9 & $0.1-3$ & $0.3-8$ & $>96 \%$ & [190] \\
\hline ZEN & Cow mixed feed & 34 & 28 & Thailand & ESI-MS/MS & $0.96-12.4$ & 5.2 & 0.19 & & $60 \%$ & {$[40]$} \\
\hline ZEN & Cow concentrate & 33 & 33 & Thailand & ESI-MS/MS & $2.5-55.6$ & 24.3 & 0.19 & & $60 \%$ & [40] \\
\hline ZEN & Feed & 61,413 & 27,559 & Global & & LOQ-105,000 & $55 *$ & & & & [167] \\
\hline ZEN & Finished feed & 19,171 & 10,676 & Global & & LOQ-9432 & 41 * & & & & [167] \\
\hline ZEN & Maize & 15,860 & 7992 & Global & & LOQ-16,495 & $77 *$ & & & & [167] \\
\hline ZEN & Maize silage & 3735 & 1508 & Global & & LOQ-6239 & 84 * & & & & [167] \\
\hline ZEN & Soybean grains & 1024 & 364 & Global & & LOQ-4336 & 43 * & & & & [167] \\
\hline ZEN & Soybean meal & 1767 & 1072 & Global & & LOQ-3720 & $47 *$ & & & & [167] \\
\hline ZEN & Wheat & 4925 & 1624 & Global & & LOQ-23,278 & $34 *$ & & & & [167] \\
\hline ZEN & Barley & 3129 & 637 & Global & & LOQ-8952 & $25 *$ & & & & [167] \\
\hline ZEN & Rice & 220 & 74 & Global & & LOQ-1530 & $60 *$ & & & & [167] \\
\hline
\end{tabular}


Table 1. Cont

\begin{tabular}{|c|c|c|c|c|c|c|c|c|c|c|c|}
\hline MYT/ISF & Food Commodity & $\begin{array}{c}\text { Samples } \\
\text { Tested }\end{array}$ & $\begin{array}{l}\text { Positive } \\
\text { Samples }\end{array}$ & Country & $\begin{array}{l}\text { Detection } \\
\text { Technique }\end{array}$ & $\begin{array}{l}\text { Concentration } \\
\text { Range }(\mu \mathrm{g} / \mathrm{kg})\end{array}$ & $\begin{array}{l}\text { Average } \\
(\mu \mathrm{g} / \mathrm{kg})\end{array}$ & $\begin{array}{l}\text { LOD } \\
(\mu \mathrm{g} / \mathrm{kg})\end{array}$ & $\begin{array}{c}\text { LOQ } \\
(\mu \mathrm{g} / \mathrm{kg})\end{array}$ & $\begin{array}{c}\text { Mean } \\
\text { Recovery }\end{array}$ & Reference \\
\hline DAI & Cow mixed feed & 34 & 17 & Thailand & ESI-MS/MS & $1013-3759$ & 2024 & 0.5 & & $70 \%$ & [40] \\
\hline Daidzin & Cow mixed feed & 34 & 16 & Thailand & ESI-MS/MS & $30-15,030$ & 5025 & 0.8 & & $47 \%$ & [40] \\
\hline Genistin & Cow mixed feed & 34 & 16 & Thailand & ESI-MS/MS & $104-20,106$ & 6824 & 0.8 & & $50 \%$ & [40] \\
\hline GLY & Cow mixed feed & 34 & 18 & Thailand & ESI-MS/MS & $129-1474$ & 652 & 0.8 & & $61 \%$ & [40] \\
\hline Glycitin & Cow mixed feed & 34 & 15 & Thailand & ESI-MS/MS & $190-3113$ & 1406 & 0.8 & & $56 \%$ & [40] \\
\hline DAI & Cow concentrate & 33 & 21 & Thailand & ESI-MS/MS & $1344-4720$ & 2678 & 0.5 & & $74 \%$ & [40] \\
\hline GEN & Cow concentrate & 33 & 21 & Thailand & ESI-MS/MS & $1319-4927$ & 3056 & 0.8 & & $107 \%$ & [40] \\
\hline Genistin & Cow concentrate & 33 & 21 & Thailand & ESI-MS/MS & $21,000-57,912$ & 33,637 & 0.8 & & $100 \%$ & [40] \\
\hline GLY & Cow concentrate & 33 & 21 & Thailand & ESI-MS/MS & 495-1686 & 1033 & 0.8 & & $64 \%$ & [40] \\
\hline Glycitin & Cow concentrate & 33 & 21 & Thailand & ESI-MS/MS & $4539-13,648$ & 8489 & 0.8 & & $100 \%$ & [40] \\
\hline Formononetin & Silage (clover) & 3 & 3 & Belgium & LC-MS/MS & $3.1-11.3$ & & $0.16 \mathrm{ng} / \mathrm{mL}$ & $0.53 \mathrm{ng} / \mathrm{mL}$ & $>79 \%$ & [191] \\
\hline Biochanin A & Silage (clover) & 3 & 3 & Belgium & LC-MS/MS & $19-24.7$ & & $0.15 \mathrm{ng} / \mathrm{mL}$ & $0.50 \mathrm{ng} / \mathrm{mL}$ & $>47 \%$ & [191] \\
\hline GEN & Silage (clover) & 3 & 2 & Belgium & LC-MS/MS & $3.9-6.2$ & & $1.3 \mathrm{ng} / \mathrm{mL}$ & $4.4 \mathrm{ng} / \mathrm{mL}$ & $>92 \%$ & [191] \\
\hline DAI & Silage (clover) & 3 & 2 & Belgium & LC-MS/MS & $4.3-8.1$ & & $0.15 \mathrm{ng} / \mathrm{mL}$ & $0.5 \mathrm{ng} / \mathrm{mL}$ & $>80 \%$ & [191] \\
\hline Formononetin & Silage (grass) & 3 & 3 & Belgium & LC-MS/MS & $14.3-49.1$ & & $0.16 \mathrm{ng} / \mathrm{mL}$ & $0.53 \mathrm{ng} / \mathrm{mL}$ & $>79 \%$ & [191] \\
\hline GEN & Silage (grass) & 3 & 3 & Belgium & LC-MS/MS & $3.1-5.7$ & & $1.3 \mathrm{ng} / \mathrm{mL}$ & $4.4 \mathrm{ng} / \mathrm{mL}$ & $>92 \%$ & [191] \\
\hline DAI & Silage (grass) & 3 & 2 & Belgium & LC-MS/MS & $2.8-10.8$ & & $0.15 \mathrm{ng} / \mathrm{mL}$ & $0.5 \mathrm{ng} / \mathrm{mL}$ & $>80 \%$ & [191] \\
\hline Formononetin & Silage (cocksfoot) & 8 & 8 & Belgium & LC-MS/MS & $444.8-687.6$ & & $0.16 \mathrm{ng} / \mathrm{mL}$ & $0.53 \mathrm{ng} / \mathrm{mL}$ & $>79 \%$ & [191] \\
\hline Biochanin A & Silage (cocksfoot) & 8 & 8 & Belgium & LC-MS/MS & $436.5-548.8$ & & $0.15 \mathrm{ng} / \mathrm{mL}$ & $0.50 \mathrm{ng} / \mathrm{mL}$ & $>47 \%$ & [191] \\
\hline GEN & Silage (cocksfoot) & 8 & 8 & Belgium & LC-MS/MS & $105.8-256.6$ & & $1.3 \mathrm{ng} / \mathrm{mL}$ & $4.4 \mathrm{ng} / \mathrm{mL}$ & $>92 \%$ & [191] \\
\hline DAI & Silage (cocksfoot) & 8 & 8 & Belgium & LC-MS/MS & $175.7-397.4$ & & $0.15 \mathrm{ng} / \mathrm{mL}$ & $0.5 \mathrm{ng} / \mathrm{mL}$ & $>80 \%$ & [191] \\
\hline Daidzin & Soybean meal & 6 & & Argentina & HPLC & $494-785$ & 596 & & & & {$[72]$} \\
\hline DAI & Soybean meal & 6 & & Argentina & HPLC & $146-203$ & 172 & & & & [72] \\
\hline Genistin & Soybean meal & 6 & & Argentina & HPLC & $930-1274$ & 1066 & & & & [72] \\
\hline GEN & Soybean meal & 6 & & Argentina & HPLC & 69-110 & 82 & & & & [72] \\
\hline Glycitin & Soybean meal & 6 & & Argentina & HPLC & $168-208$ & 181 & & & & [72] \\
\hline GLY & Soybean meal & 6 & & Argentina & HPLC & $152-279$ & 190 & & & & [72] \\
\hline
\end{tabular}


Table 1. Cont

\begin{tabular}{|c|c|c|c|c|c|c|c|c|c|c|c|}
\hline MYT/ISF & $\begin{array}{c}\text { Food } \\
\text { Commodity }\end{array}$ & $\begin{array}{l}\text { Samples } \\
\text { Tested }\end{array}$ & $\begin{array}{l}\text { Positive } \\
\text { Samples }\end{array}$ & Country & $\begin{array}{l}\text { Detection } \\
\text { Technique }\end{array}$ & $\begin{array}{l}\text { Concentration } \\
\text { Range }(\mu \mathrm{g} / \mathrm{kg})\end{array}$ & $\begin{array}{l}\text { Average } \\
(\mu \mathrm{g} / \mathrm{kg})\end{array}$ & $\begin{array}{l}\text { LOD } \\
(\mu \mathrm{g} / \mathrm{kg})\end{array}$ & $\begin{array}{c}\text { LOQ } \\
(\mu \mathrm{g} / \mathrm{kg})\end{array}$ & $\begin{array}{c}\text { Mean } \\
\text { Recovery }\end{array}$ & Reference \\
\hline Daidzin & Soybean meal & 6 & & Brazil & HPLC & $248-403$ & 298 & & & & [72] \\
\hline DAI & Soybean meal & 6 & & Brazil & HPLC & $60-143$ & 122 & & & & [72] \\
\hline GEN & Soybean meal & 6 & & Brazil & HPLC & 26-100 & 81 & & & & [72] \\
\hline Glycitin & Soybean meal & 6 & & Brazil & HPLC & $116-168$ & 142 & & & & [72] \\
\hline GLY & Soybean meal & 6 & & Brazil & HPLC & 53-93 & 67 & & & & [72] \\
\hline Daidzin & Soybean meal & 6 & & USA & HPLC & $234-257$ & 326 & & & & [72] \\
\hline Genistin & Soybean meal & 6 & & USA & HPLC & $410-688$ & 535 & & & & [72] \\
\hline GEN & Soybean meal & 6 & & USA & HPLC & $7-41$ & 24 & & & & [72] \\
\hline Glycitin & Soybean meal & 6 & & USA & HPLC & 73-137 & 113 & & & & [72] \\
\hline GLY & Soybean meal & 6 & & USA & HPLC & $71-137$ & 96 & & & & [72] \\
\hline ZEN & Pastures & 18 & 9 & Austria & LC-MS/MS & $2.62-138$ & 29.6 & & & & [170] \\
\hline Biochanin A & Pastures & 18 & 16 & Austria & LC-MS/MS & $62.1-20,650$ & 7060 & & & & [170] \\
\hline DAI & Pastures & 18 & 15 & Austria & LC-MS/MS & $5.16-6110$ & 926 & & & & [170] \\
\hline Daidzin & Pastures & 18 & 6 & Austria & LC-MS/MS & $15.8-543$ & 167 & & & & [170] \\
\hline GEN & Pastures & 18 & 15 & Austria & LC-MS/MS & $28.4-17,550$ & 2760 & & & & [170] \\
\hline GLY & Pastures & 18 & 15 & Austria & LC-MS/MS & $313-35,850$ & 7470 & & & & [170] \\
\hline
\end{tabular}

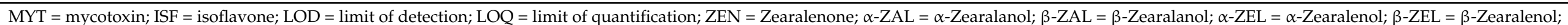
$\mathrm{GEN}=$ Genistein; $\mathrm{DAI}=$ Daidzein; $\mathrm{GLY}=$ Glycitein; values marked with * are reported as median values of positive samples. 


\subsection{Spectrum $380^{\circledR}$ Method}

In most studies, occurrence data are limited to either myco- or phytoestrogens. In general, information on the co-occurrence of phytoestrogens is scare. BIOMIN has been conducting analyses to investigate the co-occurrence of feed contaminants including mycotoxins since 2004. Ten years later Spectrum $380^{\circledR}$ was launched in cooperation with the Institute of Bioanalytics and Agro-Metabolomics of the University of Natural Resources and Life Sciences, Vienna (BOKU). Spectrum $380^{\circledR}$ is a service to customers with the aim to monitor more than 700 mycotoxins and other secondary metabolites of bacteria and fungi, 300 pesticides and 150 veterinary drugs [192]. Since the inclusion of phytoestrogens in January 2019, 1694 feed samples were analyzed. These feed samples are either finished feed or feed components which will be mixed prior to use. Tables $2-5$ provide descriptive statistics for the occurrence of ISF, ZEN, and ZEN metabolites in feed designated for different animal species.

Table 2. Occurrence of ISF and ZEN in aquaculture feed (Spectrum $380^{\circledR}$ ). Please note that ZEN and ZEN-metabolite concentrations are provided in $\mu \mathrm{g} / \mathrm{kg}$ whereas the ISF as feed constituents occur in higher concentrations and are reported in $\mathrm{mg} / \mathrm{kg}$ (factor 1000 higher).

\begin{tabular}{|c|c|c|c|c|c|c|c|}
\hline & \multicolumn{7}{|c|}{ Aqua Feed $(n=26)$} \\
\hline & DAI & Daidzin & GEN & Genistin & GLY & Glycitin & $\mathrm{ZEN}$ * \\
\hline Positive samples $(n)$ & 22 & 25 & 22 & 25 & 23 & 24 & 19 \\
\hline Positive samples (\%) & $85 \%$ & $96 \%$ & $85 \%$ & $96 \%$ & $88 \%$ & $92 \%$ & $73 \%$ \\
\hline Mean $(\mathrm{mg} / \mathrm{kg})$ & 5.90 & 17.2 & 7.91 & 26.7 & 1.66 & 9.02 & 233 \\
\hline Maximum (mg/kg) & 25.3 & 79.1 & 37.6 & 129 & 9.22 & 94.7 & 1045 \\
\hline Third quartile $(\mathrm{mg} / \mathrm{kg})$ & 6.14 & 32.7 & 15.2 & 47.4 & 2.93 & 12.4 & 334 \\
\hline Median $(\mathrm{mg} / \mathrm{kg})$ & 0.765 & 2.25 & 1.35 & 3.87 & 0.202 & 0.806 & 12.5 \\
\hline First quartile (mg/kg) & 0.195 & 0.545 & 0.343 & 0.731 & 0.0298 & 0.335 & 3.82 \\
\hline $\begin{array}{c}\text { Concentration ratio } \\
\text { ZEN/ISF }\end{array}$ & 0.04 & 0.01 & 0.03 & 0.01 & 0.14 & 0.03 & \\
\hline $\begin{array}{l}\text { Co-occurrence of ISF and } \\
\text { ZEN }(n)\end{array}$ & 15 & 18 & 15 & 18 & 16 & 17 & \\
\hline $\begin{array}{l}\text { Co-occurrence of ISF and } \\
\text { ZEN (\% of samples) }\end{array}$ & 58 & 69 & 58 & 69 & 62 & 65 & \\
\hline
\end{tabular}

Mycotoxins marked with * are reported in $\mu \mathrm{g} / \mathrm{kg} ; n=$ sample number; $\mathrm{LOQ}=$ limit of quantification; ISF = isoflavones; ZEN = Zearalenone; $\mathrm{DAI}=$ Daidzein; GEN = Genistein; GLY = Glycitein . 


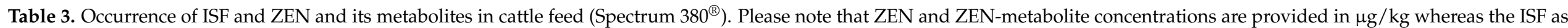
feed constituents occur in higher concentrations and are reported in $\mathrm{mg} / \mathrm{kg}$ (factor 1000 higher).

\begin{tabular}{|c|c|c|c|c|c|c|c|c|c|c|c|}
\hline & \multicolumn{11}{|c|}{ Cattle Feed $(n=542)$} \\
\hline & Biochanin A & DAI & Daidzin & Formononetin & GEN & Genistin & GLY & Glycitin & $\alpha-Z_{E L}^{*}$ & $\beta$-ZEL * & ZEN * \\
\hline Positive samples $(n)$ & 118 & 144 & 146 & 14 & 170 & 140 & 93 & 88 & 16 & 16 & 317 \\
\hline Positive samples (\%) & $22 \%$ & $27 \%$ & $27 \%$ & $3 \%$ & $31 \%$ & $26 \%$ & $17 \%$ & $16 \%$ & $3 \%$ & $3 \%$ & $58 \%$ \\
\hline Mean $(\mathrm{mg} / \mathrm{kg})$ & 2.53 & 2.75 & 4.29 & 42.8 & 3.62 & 5.91 & 2.96 & 2.48 & 15.8 & 14.1 & 42.3 \\
\hline Maximum (mg/kg) & 29.8 & 49.8 & 175 & 183 & 64.2 & 225 & 35.8 & 57.7 & 119 & 35.7 & 1305 \\
\hline Third quartile $(\mathrm{mg} / \mathrm{kg})$ & 1.67 & 1.97 & 1.39 & 36.6 & 2.66 & 1.49 & 3.22 & 1.47 & 8.88 & 20.5 & 29.9 \\
\hline Median $(\mathrm{mg} / \mathrm{kg})$ & 0.223 & 0.354 & 0.108 & 13.9 & 0.321 & 0.255 & 0.681 & 0.292 & 4.50 & 9.06 & 11.1 \\
\hline First quartile (mg/kg) & 0.028 & 0.052 & 0.028 & 5.04 & 0.036 & 0.044 & 0.123 & 0.055 & 2.78 & 6.52 & 4.09 \\
\hline Co-occurrence of ISF and ZEN $(n)$ & 60 & 85 & 86 & 8 & 100 & 78 & 57 & 58 & & & \\
\hline Co-occurrence of ISF and ZEN (\% of samples) & 11 & 16 & 16 & 1 & 18 & 14 & 11 & 11 & & & \\
\hline
\end{tabular}

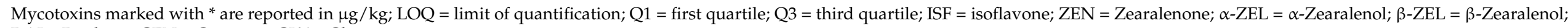
DAI = Daidzein $;$ GEN = Genistein; GLY = Glycitein .

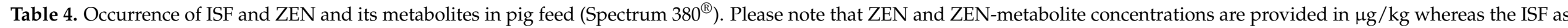
feed constituents occur in higher concentrations and are reported in $\mathrm{mg} / \mathrm{kg}$ (factor 1000 higher).

\begin{tabular}{|c|c|c|c|c|c|c|c|c|c|c|c|}
\hline & \multicolumn{11}{|c|}{ Pig Feed $(n=862)$} \\
\hline & Biochanin A & DAI & Daidzin & Formononetin & GEN & Genistin & GLY & Glycitin & $\alpha-Z_{E L}^{*}$ & $\beta-Z E L$ * & ZEN * \\
\hline Positive samples $(n)$ & 78 & 334 & 362 & 16 & 345 & 351 & 303 & 316 & 11 & 14 & 390 \\
\hline Positive samples (\%) & $9 \%$ & $39 \%$ & $42 \%$ & $2 \%$ & $40 \%$ & $41 \%$ & $35 \%$ & $37 \%$ & $1 \%$ & $2 \%$ & $45 \%$ \\
\hline Mean $(\mathrm{mg} / \mathrm{kg})$ & 4.18 & 5.98 & 40.3 & 1.66 & 9.15 & 63.3 & 2.89 & 18.5 & 25.0 & 10.7 & 115 \\
\hline Maximum (mg/kg) & 316 & 61.9 & 358 & 15.7 & 140 & 442 & 163 & 118 & 105 & 36.0 & 9905 \\
\hline Third quartile $(\mathrm{mg} / \mathrm{kg})$ & 0.018 & 8.01 & 60.0 & 0.109 & 11.4 & 86.9 & 2.34 & 21.6 & 34.8 & 13.8 & 40.0 \\
\hline Median $(\mathrm{mg} / \mathrm{kg})$ & 0.008 & 3.17 & 34.0 & 0.056 & 4.69 & 49.9 & 0.795 & 12.7 & 7.84 & 6.99 & 13.6 \\
\hline First quartile (mg/kg) & 0.003 & 1.05 & 2.36 & 0.031 & 1.23 & 6.91 & 0.369 & 4.10 & 4.87 & 5.52 & 4.96 \\
\hline Co-occurrence of ISF and ZEN $(n)$ & 56 & 252 & 263 & 13 & 254 & 257 & 236 & 246 & & & \\
\hline Co-occurrence of ISF and ZEN (\% of samples) & 6 & 29 & 31 & 2 & 29 & 30 & 27 & 29 & & & \\
\hline
\end{tabular}

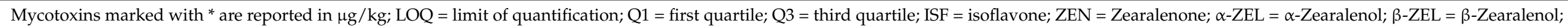
DAI = Daidzein; GEN = Genistein; GLY = Glycitein . 


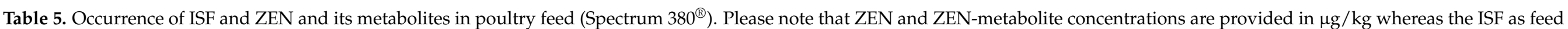
constituents occur in higher concentrations and are reported in $\mathrm{mg} / \mathrm{kg}$ (factor 1000 higher).

\begin{tabular}{|c|c|c|c|c|c|c|c|c|c|c|c|}
\hline & \multicolumn{11}{|c|}{ Poultry Feed $(n=263)$} \\
\hline & Biochanin A & DAI & Daidzin & Formononetin & GEN & Genistin & GLY & Glycitin & $\alpha-Z_{E L}^{*}$ & $\beta-Z E L$ * & ZEN * \\
\hline Positive samples $(n)$ & 13 & 176 & 205 & 2 & 191 & 212 & 159 & 168 & 10 & 18 & 177 \\
\hline Positive samples (\%) & $5 \%$ & $67 \%$ & $78 \%$ & $1 \%$ & $73 \%$ & $81 \%$ & $60 \%$ & $64 \%$ & $4 \%$ & $7 \%$ & $67 \%$ \\
\hline Mean (mg/kg) & 0.016 & 7.57 & 56.9 & 0.237 & 10.4 & 78.2 & 2.93 & 26.8 & 5.33 & 9.80 & 53.1 \\
\hline Maximum (mg/kg) & 0.124 & 53.7 & 342 & 0.306 & 102 & 465 & 37.2 & 127 & 12.6 & 58.7 & 873 \\
\hline Third quartile $(\mathrm{mg} / \mathrm{kg})$ & 0.011 & 10.2 & 86.4 & 0.271 & 14.6 & 131 & 3.32 & 37.9 & 7.45 & 6.13 & 50.4 \\
\hline Median $(\mathrm{mg} / \mathrm{kg})$ & 0.007 & 6.46 & 39.3 & 0.237 & 8.71 & 60.4 & 1.86 & 19.4 & 4.24 & 2.74 & 17.7 \\
\hline First quartile (mg/kg) & 0.004 & 1.98 & 0.790 & 0.202 & 1.12 & 0.453 & 0.67 & 6.49 & 1.75 & 1.66 & 6.95 \\
\hline Co-occurrence of ISF and ZEN $(n)$ & 11 & 142 & 155 & 1 & 149 & 158 & 129 & 136 & & & \\
\hline Co-occurrence of ISF and ZEN (\% of samples) & 4 & 54 & 59 & 0 & 57 & 60 & 49 & 52 & & & \\
\hline
\end{tabular}

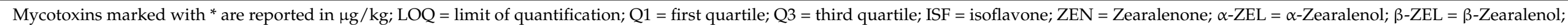

DAI = Daidzein; GEN = Genistein; GLY = Glycitein . 


\subsubsection{Aquaculture Feed}

Between January 2019 and April 2021, a total of 26 aquaculture feed samples from different countries were analyzed (Table 2) and $92 \%$ of those were classified as finished feed samples. ISF were detected in $96 \%$ of these samples. The individual ISF were present in $85 \%-96 \%$ of the feed samples (Table 2). Only GEN, DAI, and GLY and their glycosides were detected, with genistin and daidzin being the most prevalent (Table 2), suggesting that the major ISF source was soybean. Glucosides occurred in higher concentrations than their aglycons (Table 2). The mean and maximum concentrations were 7.91 and $37.6 \mathrm{mg} / \mathrm{kg}$, respectively, for GEN, and 26.7 and $129 \mathrm{mg} / \mathrm{kg}$, respectively, for its glucoside genistin. Slightly lower values were observed for DAI and its glucoside daidzin (Table 2).

In aqua feed, ZEN occurred in the medium to high $\mu \mathrm{g} / \mathrm{kg}$ range with mean and maximum concentrations of $233 \mu \mathrm{g} / \mathrm{kg}$ and $1045 \mu \mathrm{g} / \mathrm{kg}$, respectively. The prevalence of ZEN was high with detectable concentrations in $73 \%$ of the samples. The concentrations of phytoestrogens were at least one order of magnitude higher than those of ZEN (Table 2). For example, the ratio of medians was 0.04 for ZEN/DAI and 0.03 for ZEN/GEN. ISF and ZEN co-occurred in $58-69 \%$ of the samples.

\subsubsection{Cattle Feed}

ISF were detected in $43 \%$ of cattle feed samples collected from January 2019 to April $2021(n=542)$. The prevalence of the individual ISF in cattle feed ranged from $2.6 \%$ to $31 \%$ (Table 3). In addition to the ISF that were detected in the aquaculture feed samples (Section 4.2.1; Table 2), biochanin A and formononetin were detected. Formononetin even reached higher mean and median concentrations than the other ISF $(42.8 \mathrm{mg} / \mathrm{kg}$ and $13.9 \mathrm{mg} / \mathrm{kg}$, respectively; Table 3). Feed for cattle often consist of different grasses, as well as clover species rich in biochanin A and formononetin, which could explain the high concentrations of these ISF in our samples.

Detectable levels of ZEN were present in $58 \%$ of cattle feed samples with mean, median, and maximum concentrations of $42.3 \mu \mathrm{g} / \mathrm{kg}, 11.1 \mu \mathrm{g} / \mathrm{kg}$ and $1305.0 \mu \mathrm{g} / \mathrm{kg}$, respectively. ZEN metabolites ( $\alpha$-ZEL) and $\beta$-zearalenol ( $\beta$-ZEL) were detected in $3 \%$ of the tested samples. Median concentrations of phytoestrogens were at least one order of magnitude higher than those of ZEN and its metabolites $\alpha$-ZEL and $\beta$-ZEL (Table 3). The ratios of the median concentration of ZEN to the median concentration of each individual ISF were $\leq 0.02$ (Table 3). ISF and ZEN co-occurred in $24 \%$ of cattle feed samples (percentage of samples co-contaminated with ZEN and individual ISF: 1.5-18.5\%). Therefore, co-occurrence of ZEN and ISF was less frequently detected than in aquaculture (Table 2), pig (Section 4.2.3) and poultry (Section 4.2.4) feed samples.

\subsubsection{Pig Feed}

More than $40 \%$ of the samples analyzed in this study were specified as pig feed $(n=862)$. ISF were detected in up to $45 \%$ of the pig feed samples, with daidzin and genistin as well as their aglycones being the most prevalent ones (Table 4). The detected mean, median, and maximum concentrations were $9.2,4.7$ and $140.0 \mathrm{mg} / \mathrm{kg}$, respectively, for GEN and 63.3, 49.9 and $442.0 \mathrm{mg} / \mathrm{kg}$, respectively, for its glucoside genistin; DAI and its glucoside daidzin were detected at similar but somewhat lower concentrations (Table 4). Biochanin A and formononetin were only present in $9 \%$ and $2 \%$ of samples, respectively, indicating that the major source of ISF in the pig feed samples analyzed in this study were soybeans.

ZEN occurred in the low to medium $\mu \mathrm{g} / \mathrm{kg}$ range in most samples, with mean, median, and maximum concentrations of $115.0 \mu \mathrm{g} / \mathrm{kg}, 13.6 \mu \mathrm{g} / \mathrm{kg}$ and $9905.0 \mu \mathrm{g} / \mathrm{kg}$, respectively (Table 4). The prevalence of ZEN was relatively high with detectable concentrations in $45 \%$ of the samples. ZEN metabolites $\alpha$-ZEL and $\beta$-ZEL were detected in only $1.2 \%$ and $1.6 \%$ of the tested samples, respectively. ISF and ZEN co-occurred in $32 \%$ of the samples. Co-occurrence of ZEN with each individual ISF was detected in 1.5-30\% of the samples (Table 4). Median ratios of ZEN/ISF did not exceed 0.07 (Table 4). 
Pig feed was further divided into feed for 'pig' $(n=463)$, 'pig-boar' $(n=7)$, 'pigfinisher' $(n=10)$, 'pig-grower' $(n=33)$, 'pig-piglet' $(n=175)$ and 'pig-sow' $(n=172)$ (Tables S1-S6 are provided in the Supplementary Materials). The samples that were specified as 'pig' did not show a high incidence of either ISF (highest for daidzin 14\%) or ZEN (16\%) and its metabolites (Supplementary Table S1). However, the mean and median values for ISF were comparable with the values obtained for all pig feed samples (Table 4; Supplementary Tables S1-S6), whereas in the case of ZEN, the mean $(318 \mu \mathrm{g} / \mathrm{kg})$ exceeded the mean detected for all pig feed samples. The co-occurrence of ISF and ZEN for these samples was low, with the highest incidence of $6 \%$ for daidzin and ZEN. The situation was different for samples classified as 'pig-piglet', where ISF and ZEN were detected in up to $71 \%$ and $86 \%$ of samples, respectively. Mean, median and maximum concentrations were highest for genistin $(64.6,64.9$ and $260 \mathrm{mg} / \mathrm{kg}$ ), followed by daidzin and glycitin (Supplementary Table S5). The concentration of glycosides was 7-9 times higher compared to that of their aglycones, where the highest mean value was also observed for GEN, followed by DAI and GLY. The mean and maximum concentrations for ZEN were $43.1 \mu \mathrm{g} / \mathrm{kg}$ and $595 \mu \mathrm{g} / \mathrm{kg}$. ZEN co-occurred with individual soy ISF in $60-62 \%$ of the samples (Supplementary Table S5). Soy ISF were even more prevalent in 'pig-sow' feed. Here, up to $80 \%$ of all samples contained soy ISF (Supplementary Table S1). Biochanin A und formononetin were present only in a small number of samples (Supplementary Table S6). Detectable levels of ZEN were present in $73 \%$ of the 'pig-sow' feed samples with mean, median and maximum concentrations of $100 \mu \mathrm{g} / \mathrm{kg}, 17.3 \mu \mathrm{g} / \mathrm{kg}$ and $3262 \mu \mathrm{g} / \mathrm{kg}$, respectively.

The European Commission published guidance values for ZEN that should not be exceeded in certain feed commodities [36]. The mean values for the 'pig-piglet' and 'pigsow' samples were below the guidance values for these two groups (100 and $250 \mu \mathrm{g} / \mathrm{kg}$, respectively). Only the mean value of the feed classified as 'pig' exceeded the guidance values. Of all farm animals, young piglets are the most sensitive to ZEN regarding its effects on the reproduction [32]. As early as 1928, the occurrence of hyperestrogenism in swine, characterized by swelling and erythema of the vulva and uterine prolapse in gilts as well as atrophy of testicles and enlargement of nipples, could be associated with the consumption of ZEN contaminated cereals [193]. Although the feed samples declared as pig are not specified for any life stage, young piglets could be exposed to such high concentrations of ZEN, potentially adversely affecting their health.

\subsubsection{Poultry Feed}

In total, 263 poultry feed samples were analyzed for the presence of ISF and ZEN and its metabolites (Table 5). Soy ISF were present in $88 \%$ of the feed samples (occurrence of individual ISF: $60 \%-81 \%$; Table 5). Aglycones were again detected in lower concentrations by a factor of 7-10 compared to the respective glycosides (Table 5 ). The mean, median, and maximum concentrations were $10.4 \mathrm{mg} / \mathrm{kg}, 8.71 \mathrm{mg} / \mathrm{kg}$ and $102 \mathrm{mg} / \mathrm{kg}$ for GEN and $78.2 \mathrm{mg} / \mathrm{kg}, 60.4 \mathrm{mg} / \mathrm{kg}$ and $465 \mathrm{mg} / \mathrm{kg}$ for its glucoside genistin. The corresponding values for DAI and its glucoside daidzin were similar but somewhat lower compared to GEN and genistin (Table 5). Formononetin and biochanin A showed only low prevalence in poultry feed ( 0.8 and $5 \%$, respectively). The prevalence of ZEN was high, with detectable concentrations in $67 \%$ of the samples and mean, median, and maximum concentrations of $53.1 \mu \mathrm{g} / \mathrm{kg}, 17.7 \mu \mathrm{g} / \mathrm{kg}$ and $873 \mu \mathrm{g} / \mathrm{kg}$, respectively. Soy ISF and ZEN co-occurred in a high number of poultry samples (i.e., $63 \%$; co-occurrence of individual ISF with ZEN: $49-60 \%)$. The ratio of median concentrations of ZEN/soy ISF were $\leq 0.007$.

Similar to pig feed samples, poultry feed was further divided into subgroups: 'poultry' ( $n=63)$, 'poultry-breeder' $(n=31)$, 'poultry-broiler' $(n=124)$ and 'poultry-layer' $(n=38)$ (the respective Tables S7-S11 are provided in the Supplementary Materials). For the different poultry feed subgroups, the distribution, mean and maximum values for both ISF and ZEN and its metabolite were similar when compared to all poultry feed samples (Supplementary Table S2). 


\section{Conclusions}

ISF can cause both positive and negative effects in animals, depending on the species, the age and sex of the animals, and the dose and the frequency of exposure. Moderate concentrations of ISF, which occur naturally in feed, can have positive effects on growth performance, laying performance, and milk production. However, also negative effects on growth and laying performance have occasionally been observed. Furthermore, in ruminants, pigs, and fish, high concentrations of ISF were shown to negatively affect reproductive health.

Based on a literature review and analysis of 1694 feed samples with the Spectrum $380^{\circledR}$ method, it is safe to say that both the prevalence and the concentrations of ISF are high in animal feed. The predominant ISF vary between feed destined for different animal species. Although formononetin is the dominant ISF in cattle, GEN and DAI are the most abundant ISF in feed destined for other species. ISF frequently co-occur with ZEN in animal feed. Same as ISF, ZEN can have a negative effect on reproductive health. It has already been reported that combinations of even small amounts of ISF and ZEN lead to an increased estrogenic effect when compared to the potency of the single substances in vitro [41]. Such an increase in estrogenic potency resulting from combinations of these two substance classes should be investigated further in the future. Clarification is needed whether co-occurrence of these estrogen-active compounds might result in a critical shift of the endocrine activity.

Supplementary Materials: The following are available online at https:/ /www.mdpi.com/article/ 10.3390/toxins13120836/s1, Table S1: Occurrence of ISF and ZEN in pig feed (Spectrum 380 ${ }^{\circledR}$ ), Table S2: Occurrence of ISF and ZEN in pig-boar feed (Spectrum $380^{\circledR}$ ), Table S3: Occurrence of ISF and ZEN in pig-finisher feed (Spectrum $380^{\circledR}$ ), Table S4: Occurrence of ISF and ZEN in pig-grower feed (Spectrum $380^{\circledR}$ ), Table S5: Occurrence of ISF and ZEN in pig-piglet feed (Spectrum $380^{\circledR}$ ), Table S6: Occurrence of ISF and ZEN in pig-sow feed (Spectrum $380^{\circledR}$ ), Table S7: Occurrence of ISF and ZEN in poultry feed (Spectrum $380^{\circledR}$ ), Table S8: Occurrence of ISF and ZEN in poultry-breeder feed (Spectrum $380^{\circledR}$ ), Table S9: Occurrence of ISF and ZEN in poultry-broiler feed (Spectrum $380^{\circledR}$ ), Table S10: Occurrence of ISF and ZEN in poultry-layer feed (Spectrum $380^{\circledR}$ ), Table S11: Occurrence of ISF and ZEN in poultry-turkey feed (Spectrum $380^{\circledR}$ ).

Author Contributions: Conceptualization, D.G., E.V., B.N. and D.M.; writing-original draft preparation, D.G.; writing - review and editing, E.V., B.N., A.M. and D.M.; visualization, D.G.; funding acquisition, E.V., B.N. and D.M. All authors read and agreed to the published version of the manuscript.

Funding: This research was funded by the Austrian Research Promotion Agency (FFG) and BIOMIN Holding $\mathrm{GmbH}$ through the Bridge project "ISOMYCOTOX - Combinatory endocrine activity of mycoestrogens and soy isoflavones in porcine feed" (project number 880656). The APC was funded by BIOMIN Holding GmbH.

Institutional Review Board Statement: Not applicable.

Informed Consent Statement: Not applicable.

Data Availability Statement: Not applicable.

Acknowledgments: We want to acknowledge Michael Sulyok for providing us with the Spectrum $380^{\circledR}$ data. Furthermore, we want to thank Christiane Gruber-Dorninger for her input and suggestions for this review.

Conflicts of Interest: The authors declare no conflict of interest.

\section{References}

1. Mortensen, A.; Kulling, S.E.; Schwartz, H.; Rowland, I.; Ruefer, C.E.; Rimbach, G.; Cassidy, A.; Magee, P.; Millar, J.; Hall, W.L.; et al. Analytical and compositional aspects of isoflavones in food and their biological effects. Mol. Nutr. Food Res. 2009, 53, S266-S309. [CrossRef] [PubMed]

2. Křižová, L.; Dadáková, K.; Kašparovská, J.; Kašparovský, T. Isoflavones. Molecules 2019, 24, 1076. [CrossRef] [PubMed]

3. Munro, I.C.; Harwood, M.; Hlywka, J.J.; Stephen, A.M.; Doull, J.; Flamm, W.G.; Adlercreutz, H. Soy isoflavones: A safety review. Nutr. Rev. 2003, 61, 1-33. [CrossRef] [PubMed] 
4. Tham, D.M.; Gardner, C.D.; Haskell, W.L. Potential health benefits of dietary phytoestrogens: A review of the clinical, epidemiological, and mechanistic evidence. J. Clin. Endocrinol. Metab. 1998, 83, 2223-2235. [CrossRef]

5. Goldsmith, P.D. Economics of soybean production, marketing, and utilization. In Soybeans-Chemistry, Production, Processing, and Utilization; Johnson, L.A., White, P.J., Galloway, R., Eds.; Elsevier Inc.: Amsterdam, The Netherlands, 2008; pp. 117-150. [CrossRef]

6. Kurzer, M.S.; Xu, X. Dietary phytoestrogens. Annu. Rev. Nutr. 1997, 17, 353-381. [CrossRef]

7. Azam, M.; Zhang, S.; Abdelghany, A.M.; Shaibu, A.S.; Feng, Y.; Li, Y.; Tian, Y.; Hong, H.; Li, B.; Sun, J. Seed isoflavone profiling of 1168 soybean accessions from major growing ecoregions in China. Food Res. Int. 2020, 130, 108957. [CrossRef]

8. Saloniemi, H.; Wähälä, K.; Nykänen-Kurki, P.; Kallela, K.; Saastamoinen, I. Phytoestrogen Content and Estrogenic Effect of Legume Fodder. Exp. Biol. Med. 1995, 208, 13-17. [CrossRef]

9. Steinshamn, H.; Purup, S.; Thuen, E.; Hansen-Møller, J. Effects of clover-grass silages and concentrate supplementation on the content of phytoestrogens in dairy cow milk. J. Dairy Sci. 2008, 91, 2715-2725. [CrossRef]

10. Daems, F.; Romnee, J.M.; Heuskin, S.; Froidmont, É.; Lognay, G. Analytical methods used to quantify isoflavones in cow's milk: A review. Dairy Sci. Technol. 2016, 96, 261-283. [CrossRef]

11. Adler, S.A.; Purup, S.; Hansen-Møller, J.; Thuen, E.; Steinshamn, H. Phytoestrogens and their metabolites in bulk-tank milk: Effects of farm management and season. PLoS ONE 2015, 10, e0127187. [CrossRef]

12. Wang, H.J.; Murphy, P.A. Isoflavone Content in Commercial Soybean Foods. J. Agric. Food Chem. 1994, 42, 1666-1673. [CrossRef]

13. Zhengkang, H.; Wang, G.; Yao, W.; Zhu, W.Y. Isoflavonic phytoestrogens-New prebiotics for farm animals: A review on research in China. Curr. Issues Intestig. Microbiol. 2006, 7, 53-60.

14. Wilhelms, K.W.; Scanes, C.G.; Anderson, L.L. Lack of estrogenic or antiestrogenic actions of soy isoflavones in an avian model: The Japanese quail. Poult. Sci. 2006, 85, 1885-1889. [CrossRef]

15. Xiao, Y.; Mao, X.; Yu, B.; He, J.; Yu, J.; Zheng, P.; Huang, Z.; Chen, D. Potential risk of isoflavones: Toxicological study of daidzein supplementation in piglets. J. Agric. Food Chem. 2015, 63, 4228-4235. [CrossRef]

16. Chen, W.; Ma, X.; Lin, Y.; Xiong, Y.; Zheng, C.; Hu, Y.; Yu, D.; Jiang, Z. Dietary supplementation with a high dose of daidzein enhances the antioxidant capacity in swine muscle but experts pro-oxidant function in liver and fat tissues. J. Anim. Sci. Biotechnol. 2016, 7, 1-11. [CrossRef]

17. Gjorgovska, N.; Filev, K.; Levkov, V.; Kostov, V.; Nastova, R.; Gjorgjievski, S.; Grigorova, S. Effects of isoflavones in feed on plasma estradiol concentration and productive performances in laying hens. Iran. J. Appl. Anim. Sci. 2016, 6, 691-695.

18. Ren, M.Q.; Kuhn, G.; Wegner, J.; Nürnberg, G.; Chen, J.; Ender, K. Feeding daidzein to late pregnant sows influences the estrogen receptor beta and type 1 insulin-like growth factor receptor mRNA expression in newborn piglets. J. Endocrinol. 2001, 170, 129-135. [CrossRef]

19. Pace, V.; Contò, G.; Carfi, F.; Chiariotti, A.; Catillo, G. Short- and long-term effects of low estrogenic subterranean clover on ewe reproductive performance. Small Rumin. Res. 2011, 97, 94-100. [CrossRef]

20. Pace, V.; Carbone, K.; Spirito, F.; Iacurto, M.; Terzano, M.G.; Verna, M.; Vincenti, F.; Settineri, D. The effects of subterranean clover phytoestrogens on sheep growth, reproduction and carcass characteristics. Meat Sci. 2006, 74, 616-622. [CrossRef]

21. Adams, N.R. Clover phyto-oestrogens in sheep in Western Australia. Pure Appl. Chem. 1998, 70, 1855-1862. [CrossRef]

22. Kasparovska, J.; Pecinkova, M.; Dadakova, K.; Krizova, L.; Hadrova, S.; Lexa, M.; Lochman, J.; Kasparovsky, T. Effects of isoflavone-enriched feed on the rumen microbiota in dairy cows. PLoS ONE 2016, 11, e0154642. [CrossRef]

23. Bertilsson, J.; Murphy, M. Effects of feeding clover silages on feed intake, milk production and digestion in dairy cows. Grass Forage Sci. 2003, 58, 309-322. [CrossRef]

24. Dewhurst, R.J.; Fisher, W.J.; Tweed, J.K.S.; Wilkins, R.J. Comparison of grass and legume silages for milk production. 1. Production responses with different levels of concentrate. J. Dairy Sci. 2003, 86, 2598-2611. [CrossRef]

25. Li, Y.P.; Jiang, X.R.; Wei, Z.X.; Cai, L.; Yin, J.D.; Li, X.L. Effects of soybean isoflavones on the growth performance, intestinal morphology and antioxidative properties in pigs. Animal 2020, 14, 2262-2270. [CrossRef]

26. Rodríguez-Roque, M.J.; Rojas-Graü, M.A.; Elez-Martínez, P.; Martín-Belloso, O. Soymilk phenolic compounds, isoflavones and antioxidant activity as affected by in vitro gastrointestinal digestion. Food Chem. 2013, 136, 206-212. [CrossRef]

27. Hashem, N.; Soltan, Y. Impacts of Phytoestrogens on Livestock Production: A Review. Egypt. J. Nutr. Feed. 2016, 19, 81-89. [CrossRef]

28. Bennetts, H.W.; Uuderwood, E.J.; Shier, F.L. A Specific Breeding Problem of Sheep on Subterranean Clover Pastures in Western Australia. Aust. Vet. J. 1946, 22, 2-12. [CrossRef]

29. Urry, W.H.; Wehrmeister, H.L.; Hodge, E.B.; Hidy, P.H. The structure of zearalenone. Tetrahedron Lett. 1966, 7, 3109-3114. [CrossRef]

30. Rai, A.; Das, M.; Tripathi, A. Occurrence and toxicity of a fusarium mycotoxin, zearalenone. Crit. Rev. Food Sci. Nutr. 2020, 60, 2710-2729. [CrossRef] [PubMed]

31. Fink-Gremmels, J.; Malekinejad, H. Clinical effects and biochemical mechanisms associated with exposure to the mycoestrogen zearalenone. Anim. Feed Sci. Technol. 2007, 137, 326-341. [CrossRef]

32. Kuiper-Goodman, T.; Scott, P.M.; Watanabe, H. Risk Assessment of the Mycotoxin Zearalenone. Regul. Toxicol. Pharmacol. 1987, 7, 253-306. [CrossRef] 
33. Mirocha, C.J.; Harrison, J.; Nichols, A.A.; McClintock, M. Detection of a fungal estrogen (F-2) in hay associated with infertility in dairy cattle. Appl. Microbiol. 1968, 16, 797-798. [CrossRef] [PubMed]

34. Döll, S.; Dänicke, S. The Fusarium toxins deoxynivalenol (DON) and zearalenone (ZON) in animal feeding. Prev. Vet. Med. 2011, 102, 132-145. [CrossRef] [PubMed]

35. European Commission. Comission Recommendation of 17 August 2006 on the presence of deoxynivalenol, zearalenone, ochratoxin A, T-2 and HT-2 and fumonisins in products intended for animal feeding (2006/576/EC). Off. J. Eur. Union 2006, 10, 7-9.

36. Commission of the European Community. Commision Regulation (EC) No 2016/1319 of 29 July 2016-Amending Recommendation 2006/576/EC as regards deoxynivalenol, zearalenone and ochratoxin A in pet food. Off. J. Eur. Union 2016, 73, 58-60.

37. Munkvold, G.P.; Arias, S.; Taschl, I.; Gruber-Dorninger, C. Mycotoxins in Corn: Occurrence, Impacts, and Management. In Serna-Saldivar, S.O.: Corn, 3rd ed.; Elsevier Inc.: Duxford, UK, 2018; ISBN 9780128119716.

38. Eskola, M.; Kos, G.; Elliott, C.T.; Hajšlová, J.; Mayar, S.; Krska, R. Worldwide contamination of food-crops with mycotoxins: Validity of the widely cited 'FAO estimate' of 25\%. Crit. Rev. Food Sci. Nutr. 2020, 60, 2773-2789. [CrossRef]

39. Zinedine, A.; Soriano, J.M.; Moltó, J.C.; Mañes, J. Review on the toxicity, occurrence, metabolism, detoxification, regulations and intake of zearalenone: An oestrogenic mycotoxin. Food Chem. Toxicol. 2007, 45, 1-18. [CrossRef]

40. Awapak, D.; Petchkongkaew, A.; Sulyok, M.; Krska, R.; Awapak, D.; Petchkongkaew, A.; Sulyok, M. Co-occurrence and toxicological relevance of secondary metabolites in dairy cow feed from Thailand. Food Addit. Contam. Part A 2021, 38, $1013-1027$. [CrossRef]

41. Vejdovszky, K.; Schmidt, V.; Warth, B.; Marko, D. Combinatory estrogenic effects between the isoflavone genistein and the mycotoxins zearalenone and alternariol in vitro. Mol. Nutr. Food Res. 2017, 61, e1600526. [CrossRef]

42. Iqbal, M.F.; Zhu, W.Y. Characterization of newly isolated Lactobacillus delbrueckii-like strain MF-07 isolated from chicken and its role in isoflavone biotransformation: Research Letter. FEMS Microbiol. Lett. 2009, 291, 180-187. [CrossRef]

43. Iqbal, Y.; Cottrell, J.J.; Suleria, H.A.R.; Dunshea, F.R. Gut microbiota-polyphenol interactions in chicken: A review. Animals 2020, 10, 1391. [CrossRef]

44. Walsh, K.R.; Haak, S.J.; Fastinger, N.D.; Bohn, T.; Tian, Q.; Mahan, D.C.; Schwartz, S.J.; Failla, M.L. Gastrointestinal absorption and metabolism of soy isoflavonoids in ileal-canulated swine. Mol. Nutr. Food Res. 2009, 53, 277-286. [CrossRef]

45. Cassidy, A.; Brown, J.E.; Hawdon, A.; Faughnan, M.S.; King, L.J.; Millward, J.; Zimmer-Nechemias, L.; Wolfe, B.; Setchelly, K.D.R. Factors affecting the bioavailability of soy isoflavones in humans after ingestion of physiologically relevant levels from different soy foods. J. Nutr. 2006, 136, 45-51. [CrossRef]

46. Rüfer, C.E.; Maul, R.; Donauer, E.; Fabian, E.J.; Kulling, S.E. In vitro and in vivo metabolism of the soy isoflavone glycitein. Mol. Nutr. Food Res. 2007, 51, 813-823. [CrossRef]

47. Coldham, N.G.; Darby, C.; Hows, M.; King, L.J.; Zhang, A.Q.; Sauer, M.J. Comparative metabolism of genistin by human and rat gut microflora: Detection and identification of the end-products of metabolism. Xenobiotica 2002, 32, 45-62. [CrossRef]

48. Nilsson, A.; Hill, J.L. An in vitro study of formononetin and biochanin A metabolism in rumen fluid from sheep. Biochim. Biophys. Acta (BBA)—Lipids Lipid Metab. 1967, 148, 92-98. [CrossRef]

49. Chang, Y.C.; Nair, M.G. Metabolism of daidzein and genistein by intestinal bacteria. J. Nat. Prod. 1995, 58, 1892-1896. [CrossRef]

50. Dickinson, J.M.; Smith, G.R.; Randel, R.D.; Pemberton, I.J. In vitro metabolism of formononetin amd biochanin A in bovine rumen fluid. J. Anim. Sci. 1988, 66, 1969-1973. [CrossRef]

51. Lundh, T.J.O.; Pettersson, H.I.; Martinsson, K.A. Comparative Levels of Free and Conjugated Plant Estrogens in Blood Plasma of Sheep and Cattle Fed Estrogenic Silage. J. Agric. Food Chem. 1990, 38, 1530-1534. [CrossRef]

52. Mustonen, E.A.; Jokela, T.; Saastamoinen, I.; Taponen, J.; Taponen, S.; Saloniemi, H.; Wähälä, K. High serum S-equol content in red clover fed ewes: The classical endocrine disruptor is a single enantiomer. Environ. Chem. Lett. 2006, 3, 154-159. [CrossRef]

53. Gu, L.; House, S.E.; Prior, R.L.; Fang, N.; Ronis, M.J.J.; Clarkson, T.B.; Wilson, M.E.; Badger, T.M. Metabolic phenotype of isoflavones differ among female rats, pigs, monkeys, and women. J. Nutr. 2006, 136, 1215-1221. [CrossRef]

54. Wang, X.L.; Shin, K.H.; Hur, H.G.; Kim, S. Il Enhanced biosynthesis of dihydrodaidzein and dihydrogenistein by a newly isolated bovine rumen anaerobic bacterium. J. Biotechnol. 2005, 115, 261-269. [CrossRef]

55. Gao, X.; Mu, P.; Zhu, X.; Chen, X.; Tang, S.; Wu, Y.; Miao, X.; Wang, X.; Wen, J.; Deng, Y. Dual function of a novel bacterium, slackia sp. D-G6: Detoxifying deoxynivalenol and producing the Natural Estrogen Analogue, Equol. Toxins 2020, 12, 85. [CrossRef]

56. Yu, Z.T.; Yao, W.; Zhu, W.Y. Isolation and identification of equol-producing bacterial strains from cultures of pig faeces. FEMS Microbiol. Lett. 2008, 282, 73-80. [CrossRef]

57. Kulling, S.E.; Honig, D.M.; Simat, T.J.; Metzler, M. Oxidative in vitro metabolism of the soy phytoestrogens daidzein and genistein. J. Agric. Food Chem. 2000, 48, 4963-4972. [CrossRef]

58. Roberts-Kirchhoff, E.S.; Crowley, J.R.; Hollenberg, P.F.; Kim, H. Metabolism of genistein by rat and human cytochrome P450s. Chem. Res. Toxicol. 1999, 12, 610-616. [CrossRef]

59. Rüfer, C.E.; Glatt, H.; Kulling, S.E. Structural elucidation of hydroxylated metabolites of the isoflavan equol by gas chromatography-mass spectrometry and high-performance liquid chromatography-mass spectrometry. Drug Metab. Dispos. 2006, 34, 51-60. [CrossRef] 
60. Lundh, T.J.O.; Pettersson, H.; Kiessling, K.H. Demethylation and conjugation of formononetin and daidzein in sheep and cow liver microsomes. J. Agric. Food Chem. 1988, 36, 22-25. [CrossRef]

61. Heinonen, S.M.; Wähälä, K.; Liukkonen, K.H.; Aura, A.M.; Poutanen, K.; Adlercreutz, H. Studies of the In Vitro Intestinal Metabolism of Isoflavones Aid in the Identification of Their Urinary Metabolites. J. Agric. Food Chem. 2004, 52, 2640-2646. [CrossRef]

62. Kulling, S.E.; Honig, D.M.; Metzler, M. Oxidative metabolism of the soy isoflavones daidzein and genistein in humans in vitro and in vivo. J. Agric. Food Chem. 2001, 49, 3024-3033. [CrossRef]

63. Murota, K.; Nakamura, Y.; Uehara, M. Flavonoid metabolism: The interaction of metabolites and gut microbiota. Biosci. Biotechnol. Biochem. 2018, 82, 600-610. [CrossRef] [PubMed]

64. Setchell, K.D.R.; Gosselin, S.J.; Welsh, M.B.; Johnston, J.O.; Balistreri, W.F.; Kramer, L.W.; Dresser, B.L.; Tarr, M.J. Dietary estrogens-A probable cause of infertility and liver disease in captive cheetahs. Gastroenterology 1987, 93, 225-233. [CrossRef]

65. Rüfer, C.E.; Bub, A.; Möseneder, J.; Winterhalter, P.; Stürtz, M.; Kulling, S.E. Pharmacokinetics of the soybean isoflavone daidzein in its aglycone and glucoside form: A randomized, double-blind, crossover study. Am. J. Clin. Nutr. 2008, 87, 1314-1323. [CrossRef] [PubMed]

66. Nakano, H.; Ogura, K.; Takahashi, E.; Harada, T.; Nishiyama, T.; Muro, K.; Hiratsuka, A.; Kadota, S.; Watabe, T. Regioselective monosulfation and disulfation of the phytoestrogens daidzein and genistein by human liver sulfotransferases. Drug Metab. Pharmacokinet. 2004, 19, 216-226. [CrossRef]

67. Clarke, D.B.; Lloyd, A.S.; Botting, N.P.; Oldfield, M.F.; Needs, P.W.; Wiseman, H. Measurement of intact sulfate and glucuronide phytoestrogen conjugates in human urine using isotope dilution liquid chromatography-tandem mass spectrometry with [13C3]isoflavone internal standards. Anal. Biochem. 2002, 309, 158-172. [CrossRef]

68. Soukup, S.T.; Helppi, J.; Müller, D.R.; Zierau, O.; Watzl, B.; Vollmer, G.; Diel, P.; Bub, A.; Kulling, S.E. Phase II metabolism of the soy isoflavones genistein and daidzein in humans, rats and mice: A cross-species and sex comparison. Arch. Toxicol. 2016, 90, 1335-1347. [CrossRef]

69. Liu, L.; Klaassen, C.D. Ontogeny and hormonal basis of female-dominant rat hepatic sulfotransferases. J. Pharmacol. Exp. Ther. 1996, 279, 386-391.

70. Sfakianos, J.; Coward, L.; Kirk, M.; Barnes, S. Intestinal uptake and biliary excretion of the isoflavone genistein in rats. J. Nutr. 1997, 127, 1260-1268. [CrossRef]

71. Lundh, T.J.O. Conjugation of the Plant Estrogens Formononetin and Daidzein and Their Metabolite Equol by Gastrointestinal Epithelium from Cattle and Sheep. J. Agric. Food Chem. 1990, 38, 1012-1016. [CrossRef]

72. Flachowsky, G.; Hünerberg, M.; Meyer, U.; Kammerer, D.R.; Carle, R.; Goerke, M.; Eklund, M. Isoflavone concentration of soybean meal from various origins and transfer of isoflavones into milk of dairy cows. J. Consum. Prot. Food Saf. 2011, 6, 449-456. [CrossRef]

73. Urpi-Sarda, M.; Morand, C.; Besson, C.; Kraft, G.; Viala, D.; Scalbert, A.; Besle, J.M.; Manach, C. Tissue distribution of isoflavones in ewes after consumption of red clover silage. Arch. Biochem. Biophys. 2008, 476, 205-210. [CrossRef]

74. Lindner, H.R. Study of the fate of phyto-oestrogens in the sheep by determination of isoflavones and coumestrol in the plasma and adipose tissue. Aust. J. Agric. Res. 1967, 18, 305-333. [CrossRef]

75. Degen, G.; Janning, P.; Diel, P.; Michna, H.; Bolt, H. Transplacental transfer of the phytoestrogen daidzein in DA/Han rats. Arch. Toxicol. 2002, 76, 23-29. [CrossRef]

76. Weber, K.S.; Jacobson, N.A.; Setchelly, K.D.R.; Lephart, E.D. Brain Aromatase and $5 \alpha$-Reductase, Regulatory Behaviors and Testosterone Levels in Adult Rats on Phytoestrogen Diets. Proc. Soc. Exp. Biol. Med. 1999, 221, 131-135. [CrossRef]

77. Chang, H.C.; Churchwell, M.I.; Delclos, K.B.; Newbold, R.R.; Doerge, D.R. Mass spectrometric determination of genistein tissue distribution diet- exposed Sprague-Dawley rats. J. Nutr. 2000, 130, 1963-1970. [CrossRef]

78. Gilani, G.S.; Farmer, C.; Dyck, M.; Robertson, P.; Dahiya, J.; Sepehr, E.; Fan, L.; Nicolidakis, H.; Curran, I.; Cooke, G.M. Distribution of isoflavones in samples of serum, liver and mammary glands of rats or pigs fed dietary isoflavones. Ann. Nutr. Metab. 2011, 58, 171-180. [CrossRef]

79. Sepehr, E.; Cooke, G.M.; Robertson, P.; Gilani, G.S. Effect of glycosidation of isoflavones on their bioavailability and pharmacokinetics in aged male rats. Mol. Nutr. Food Res. 2009, 53, 16-26. [CrossRef]

80. Rowland, I.; Wiseman, H.; Sanders, T.; Adlercreutz, H.; Bowey, E. Metabolism of oestrogens and phytoestrogens: Role of the gut microflora. Biochem. Soc. Trans. 1999, 27, 304-308. [CrossRef]

81. Setchell, K.D.R.; Cassidy, A. Symposium on Phytochemicals: Biochemistry and Physiology Dietary Isoflavones: Biological Effects and Relevance to Human Health. J. Nutr. 1999, 129, 758-767. [CrossRef]

82. Uehara, M.; Ohta, A.; Sakai, K.; Suzuki, K.; Watanabe, S.; Adlercreutz, H. Dietary fructooligosaccharides modify intestinal bioavailability of a single dose of genistein and daidzein and affect their urinary excretion and kinetics in blood of rats. J. Nutr. 2001, 131, 787-795. [CrossRef]

83. Wang, Q.; Li, H.; Tao, P.; Wang, Y.P.; Yuan, P.; Yang, C.X.; Li, J.Y.; Yang, F.; Lee, H.; Huang, Y. Soy isoflavones, CYP1A1, CYP1B1, and COMT polymorphisms, and breast cancer: A case-control study in southwestern China. DNA Cell Biol. 2011, 30, 585-595. [CrossRef] 
84. Wakeling, L.A.; Ford, D. Polymorphisms in genes involved in the metabolism and transport of soy isoflavones affect the urinary metabolite profile in premenopausal women following consumption of a commercial soy supplement as a single bolus dose. Mol. Nutr. Food Res. 2012, 56, 1794-1802. [CrossRef]

85. Lundh, T. Metabolism of Estrogenic Isoflavones in Domestic Animals. Proc. Soc. Exp. Biol. Med. 1995, 208, 33-39. [CrossRef]

86. Millington, A.J.; Francis, C.M.; McKeown, N.R. Wether bioassay of annual pasture legumesii the oestrogenic activity of nine strains of Trifolium subterraneum L. Aust. J. Agric. Res. 1964, 15, 527-536. [CrossRef]

87. Adams, N.R. Detection of the effects of phytoestrogens on sheep and cattle. J. Anim. Sci. 1995, 73, 1509-1515. [CrossRef]

88. Trnková, A.; Šancová, K.; Zapletalová, M.; Kašparovská, J.; Dadáková, K.; Křížová, L.; Lochman, J.; Hadrová, S.; Ihnatová, I.; Kašparovský, T. Determination of in vitro isoflavone degradation in rumen fluid. J. Dairy Sci. 2018, 101, 5134-5144. [CrossRef]

89. Koligian, K.B.; Stormshak, F. Nuclear and cytoplasmic estrogen receptors in ovine endometrium during the estrous cycle. Endocrinology 1977, 101, 524-533. [CrossRef]

90. Henricks, D.M.; Harris, R.B. Cytoplasmic estrogen receptors and estrogen concentrations in bovine uterine endometrium. Endocrinology 1978, 103, 176-185. [CrossRef]

91. Markiewicz, L.; Garey, J.; Adlercreutz, H.; Gurpide, E. Bioassays of Non-Steroidal Phytoestrogens. J. Steroid Biochem. Mol. Biol. 1993, 45, 399-405. [CrossRef]

92. Rawlings, N.C.; Cook, S.J. LH secretion around the time of the preovulatory gonadotrophin surge in the ewe. Anim. Reprod. Sci. 1993, 30, 289-299. [CrossRef]

93. Kuhn, G.; Hennig, U.; Kalbe, C.; Rehfeldt, C.; Ren, M.Q.; Moors, S.; Degen, G.H. Growth performance, carcass characteristics and bioavailability of isoflavones in pigs fed soy bean based diets. Arch. Anim. Nutr. 2004, 58, 265-276. [CrossRef] [PubMed]

94. Wong, C.-K.; Keung, W.M. Daidzein Sulfoconjugates Are Potent Inhibitors. Biochem. Biophys. Res. Commun. 1997, 583, 579-583. [CrossRef] [PubMed]

95. Pasqualini, J.R.; Gelly, C.; Nguyen, B.-L. Metabolism and Biologic Response of Estrogen Sulfates in Hormone-Dependent and Hormone-Independent Mammary Cancer Cell Lines. Effect of Antiestrogens. Ann. N. Y. Acad. Sci. 1990, 595, 106-116. [CrossRef] [PubMed]

96. Saitoh, S.; Sato, T.; Harada, H.; Takita, T. Transfer of soy isoflavone into the egg yolk of chickens. Biosci. Biotechnol. Biochem. 2001, 65, 2220-2225. [CrossRef]

97. Saitoh, S.; Sato, T.; Harada, H.; Matsuda, T. Biotransformation of soy isoflavone-glycosides in laying hens: Intestinal absorption and preferential accumulation into egg yolk of equol, a more estrogenic metabolite of daidzein. Biochim. Biophys. Acta Gen. Subj. 2004, 1674, 122-130. [CrossRef]

98. Purup, B.S.; Hansen-Møller, J.; Sejrsen, K.; Health, A. Increased Phytoestrogen Content in Organic Milk and the Biological Importance; Newsletter from Danish Reasearch Centre for Organic Farming. 2004. Available online: http://www.darcof.dk/ enews/june04/defence.html (accessed on 18 October 2021).

99. King, R.A.; Mano, M.M.; Head, R.J. Assessment of isoflavonoid concentrations in Australian bovine milk samples. J. Dairy Res. 1998, 65, 479-489. [CrossRef]

100. Krenn, L.; Unterrieder, I.; Ruprechter, R. Quantification of isoflavones in red clover by high-performance liquid chromatography. J. Chromatogr. B Anal. Technol. Biomed. Life Sci. 2002, 777, 123-128. [CrossRef]

101. Halling, M.A.; Topp, C.F.E.; Doyle, C.J. Aspects of the productivity of forage legumes in Northern Europe. Grass Forage Sci. 2004, 59, 331-344. [CrossRef]

102. Vanhatalo, A.; Kuoppala, K.; Ahvenjärvi, S.; Rinne, M. Effects of feeding grass or red clover silage cut at two maturity stages in dairy cows. 1. Nitrogen metabolism and supply of amino acids. J. Dairy Sci. 2009, 92, 5620-5633. [CrossRef]

103. Antignac, J.P.; Cariou, R.; Le Bizec, B.; Cravedi, J.P.; Andre, F. Identification of phytoestrogens in bovine milk using liquid chromatography/electrospray tandem mass spectrometry. Rapid Commun. Mass Spectrom. 2003, 17, 1256-1264. [CrossRef]

104. Antignac, J.P.; Cariou, R.; Le Bizec, B.; André, F. New data regarding phytoestrogens content in bovine milk. Food Chem. 2004, 87, 275-281. [CrossRef]

105. Andersen, C.; Weisbjerg, M.R.; Hansen-Mller, J.; Sejrsen, K. Effect of forage on the content of phyto-oestrogens in bovine milk. Animal 2009, 3, 617-622. [CrossRef]

106. Andersen, C.; Nielsen, T.S.; Purup, S.; Kristensen, T.; Eriksen, J.; Søegaard, K.; Sørensen, J.; Fretté, X.C. Phyto-oestrogens in herbage and milk from cows grazing white clover, red clover, lucerne or chicory-rich pastures. Animal 2009, 3, 1189-1195. [CrossRef]

107. Moorby, J.M.; Fraser, M.D.; Theobald, V.J.; Wood, J.D.; Haresign, W. The effect of red clover formononetin content on live-weight gain, carcass characteristics and muscle equol content of finishing lambs. Anim. Sci. 2004, 79, 303-313. [CrossRef]

108. Fraser, M.D.; Speijers, M.H.M.; Theobald, V.J.; Fychan, R.; Jones, R. Production performance and meat quality of grazing lambs finished on red clover, lucerne or perennial ryegrass swards. Grass Forage Sci. 2004, 59, 345-356. [CrossRef]

109. Graves, M.E.; McLean, N.; Jones, G.; Martin, R.C. Pasture and sheep performance response to sod-seeding red clover (Trifolium pratense L.) or white clover (Trifolium repens L.) into naturalized pastures in eastern Canada. Anim. Feed Sci. Technol. 2012, 177, 7-14. [CrossRef]

110. Speijers, M.H.M.; Fraser, M.D.; Theobald, V.J.; Haresign, W. Effects of ensiled forage legumes on performance of store finishing lambs. Anim. Feed Sci. Technol. 2005, 120, 203-216. [CrossRef] 
111. Wocławek-Potocka, I.; Mannelli, C.; Boruszewska, D.; Kowalczyk-Zieba, I.; Waśniewski, T.; Skarzyński, D.J. Diverse effects of phytoestrogens on the reproductive performance: Cow as a model. Int. J. Endocrinol. 2013, 2013, 650984. [CrossRef]

112. Woclawek-Potocka, I.; Bah, M.M.; Korzekwa, A.; Piskula, M.K.; Wiczkowski, W.; Depta, A.; Skarzynski, D.J. Soybean-derived phytoestrogens regulate prostaglandin secretion in endometrium during cattle estrous cycle and early pregnancy. Exp. Biol. Med. 2005, 230, 189-199. [CrossRef]

113. Waghorn, G.C.; McNabb, W.C. Consequences of plant phenolic compounds for productivity and health of ruminants. Proc. Nat. 2003, 62, 383-392. [CrossRef]

114. Kallela, K.; Heinonen, K.; Saloniemi, H. Plant oestrogens; the cause of decreased fertility in cows. A case report. Nord. Vet. 1984, $36,124-129$.

115. Thain, R. Bovine infertility possibly caused by subterranean clover: A preliminary report. Aust. Vet. J. 1965, 41, $277-281$. [CrossRef]

116. Austin, A.R.; Aston, K.; Drane, H.M.; Saba, N. The fertility of heifers consuming red clover silage. Grass Forage Sci. 1982, 37, 101-106. [CrossRef]

117. Lightfoot, R.J.; Smith, J.E.; Cumming, I.A.; Marshall, T.; Wroth, R.H.; Hearnshaw, H. Infertility in ewes caused by prolonged grazing on oestrogenic pastures: Oestrus, fertilization and cervical mucus. Aust. J. Biol. Sci. 1974, 27, 409-414. [CrossRef]

118. Adams, N.R. Permanent infertility in ewes exposed to plant oestrogens. Aust. Vet. J. 1990, 67, 197-201. [CrossRef]

119. Adams, N.R. Organizational and Activational Effects of Phytoestrogens on the Reproductive Tract of the Ewe. Proc. Soc. Exp. Biol. Med. 1995, 208, 87-91. [CrossRef]

120. Hashem, N.M.; El-Azrak, K.M.; Nour El-Din, A.N.M.; Sallam, S.M.; Taha, T.A.; Salem, M.H. Effects of Trifolium alexandrinum phytoestrogens on oestrous behaviour, ovarian activity and reproductive performance of ewes during the non-breeding season. Anim. Reprod. Sci. 2018, 196, 1-8. [CrossRef]

121. Mustonen, E.; Taponen, S.; Andersson, M.; Sukura, A.; Katila, T.; Taponen, J. Fertility and growth of nulliparous ewes after feeding red clover silage with high phyto-oestrogen concentrations. Animal 2014, 8, 1699-1705. [CrossRef] [PubMed]

122. Gunnarsson, D.; Selstam, G.; Ridderstråle, Y.; Holm, L.; Ekstedt, E.; Madej, A. Effects of dietary phytoestrogens on plasma testosterone and triiodothyronine (T3) levels in male goat kids. Acta Vet. Scand. 2009, 51, 51. [CrossRef] [PubMed]

123. Höjer, A.; Adler, S.; Purup, S.; Hansen-Møller, J.; Martinsson, K.; Steinshamn, H.; Gustavsson, A.M. Effects of feeding dairy cows different legume-grass silages on milk phytoestrogen concentration. J. Dairy Sci. 2012, 95, 4526-4540. [CrossRef] [PubMed]

124. Payne, R.L.; Bidner, T.D.; Southern, L.L.; Geaghan, J.P. Effects of dietary soy isoflavones on growth, carcass traits, and meat quality in growing-finishing pigs. J. Anim. Sci. 2001, 79, 1230-1239. [CrossRef]

125. Zhu, C.; Wu, Y.; Jiang, Z.; Zheng, C.; Wang, L.; Yang, X.; Ma, X.; Gao, K.; Hu, Y. Dietary soy isoflavone attenuated growth performance and intestinal barrier functions in weaned piglets challenged with lipopolysaccharide. Int. Immunopharmacol. 2015, 28, 288-294. [CrossRef]

126. Hu, Y.J.; Gao, K.G.; Zheng, C.T.; Wu, Z.J.; Yang, X.F.; Wang, L.; Ma, X.Y.; Zhou, A.G.; Jiang, Z.J. Effect of dietary supplementation with glycitein during late pregnancy and lactation on antioxidative indices and performance of primiparous sows. J. Anim. Sci. 2015, 93, 2246-2254. [CrossRef]

127. Rochell, S.J.; Alexander, L.S.; Rocha, G.C.; Van Alstine, W.G.; Boyd, R.D.; Pettigrew, J.E.; Dilger, R.N. Effects of dietary soybean meal concentration on growth and immune response of pigs infected with porcine reproductive and respiratory syndrome virus J. Anim. Sci. 2015, 93, 2987-2997. [CrossRef]

128. Smith, B.; Morris, A.; Oelschlager, M.; Connor, J.; Dilger, R. Effects of dietary soy isoflavones and soy protein source on response of weanling pigs to porcine reproductive and respiratory syndrome viral infection. J. Anim. Sci. 2019, 97, 2989-3006. [CrossRef]

129. Greiner, L.L.; Stahly, T.S.; Stabel, T.J. The effect of dietary soy genistein on pig growth and viral replication during a viral challenge. J. Anim. Sci. 2001, 79, 1272-1279. [CrossRef]

130. Smith, B.N.; Oelschlager, M.L.; Abdul Rasheed, M.S.; Dilger, R.N. Dietary soy isoflavones reduce pathogen-related mortality in growing pigs under porcine reproductive and respiratory syndrome viral challenge. J. Anim. Sci. 2020, 98, skaa024. [CrossRef]

131. Zheng, W.; Hou, Y.; Yao, W. Lactulose increases equol production and improves liver antioxidant status in barrows treated with daidzein. PLoS ONE 2014, 9, e93163. [CrossRef]

132. Yuan, X.X.; Zhang, B.; Li, L.L.; Xiao, C.W.; Fan, J.X.; Geng, M.M.; Yin, Y.L. Effects of soybean isoflavones on reproductive parameters in Chinese mini-pig boars. J. Anim. Sci. Biotechnol. 2012, 3, 31. [CrossRef]

133. Fan, J.; Zhang, B.; Li, L.; Xiao, C.; Oladele, O.A.; Jiang, G.; Ding, H.; Wang, S.; Xing, Y.; Xiao, D.; et al. Effect of soyabean isoflavones exposure on onset of puberty, serum hormone concentration and gene expression in hypothalamus, pituitary gland and ovary of female bama miniature pigs. Asian-Australas. J. Anim. Sci. 2015, 28, 1573-1582. [CrossRef]

134. Drane, H.M.; Wrathall, A.E.; Patterson, D.S.P.; Hebert, C.N. Possible oestrogenic effects of feeding soyameal to prepuberal gilts. Br. Vet. J. 1981, 137, 283-288. [CrossRef]

135. Ford, J.A.; Clark, S.G.; Walters, E.M.; Wheeler, M.B.; Hurley, W.L. Estrogenic effects of genistein on reproductive tissues of ovariectomized gilts. J. Anim. Sci. 2006, 84, 834-842. [CrossRef]

136. Bitsch, N.; Körner, W.; Postupka, S.; Brunn, H. Application of the E-screen assay to test for oestrogenically active substances in swine feed. J. Anim. Physiol. Anim. Nutr. 2001, 85, 369-377. [CrossRef]

137. Zhao, R.Q.; Zhou, Y.C.; Ni, Y.D.; Lu, L.Z.; Tao, Z.R.; Chen, W.H.; Chen, J. Effect of daidzein on egg-laying performance in Shaoxing duck breeders during different stages of the egg production cycle. Br. Poult. Sci. 2005, 46, 175-181. [CrossRef] 
138. Abdelghani, E.; Xing, W.; Li, Y.; Shen, D.; Alsiddig, M.A.; Li, C. Effects of dietary supplementation of soy isoflavones on the performance and egg quality in native chinese breeder hens. Rev. Bras. Cienc. Avic. 2019, 21, 1-8. [CrossRef]

139. Lu, J.; Qu, L.; Shen, M.M.; Li, S.M.; Dou, T.C.; Hu, Y.P.; Wang, K.H. Safety evaluation of daidzein in laying hens: Effects on laying performance, hatchability, egg quality, clinical blood parameters, and organ development. Poult. Sci. 2017, 96, 2098-2103. [CrossRef]

140. Kamboh, A.A.; Zhu, W.Y. Effect of increasing levels of bioflavonoids in broiler feed on plasma anti-oxidative potential, lipid metabolites, and fatty acid composition of meat. Poult. Sci. 2013, 92, 454-461. [CrossRef]

141. Zhao, X.; Shao, T.; Wang, Y.Q.; Lu, X.L.; Luo, J.B.; Zhou, W.D. The phytoestrogen daidzein may affect reproductive performance of Zhedong White geese by regulating gene mRNA levels in the HPG axis. Br. Poult. Sci. 2013, 54, 252-258. [CrossRef] [PubMed]

142. Ni, Y.; Zhu, Q.; Zhou, Z.; Grossmann, R.; Chen, J.; Zhao, R. Effect of dietary daidzein on egg production, shell quality, and gene expression of ER- $\alpha$, GH-R, and IGF-IR in shell glands of laying hens. J. Agric. Food Chem. 2007, 55, 6997-7001. [CrossRef] [PubMed]

143. Sahin, K.; Akdemir, F.; Tuzcu, M.; Sahin, N.; Onderci, M.; Ozercan, R.; Ilhan, N.; Kilic, E.; Seren, S.; Kucuk, O. Genistein suppresses spontaneous oviduct tumorigenesis in quail. Nutr. Cancer 2009, 61, 799-806. [CrossRef]

144. Payne, R.L.; Bidner, T.D.; Southern, L.L.; McMillin, K.W. Dietary effects of soy isoflavones on growth and carcass traits of commercial broilers. Poult. Sci. 2001, 80, 1201-1207. [CrossRef] [PubMed]

145. Jiang, Z.Y.; Jiang, S.Q.; Lin, Y.C.; Xi, P.B.; Yu, D.Q.; Wu, T.X. Effects of soybean isoflavone on growth performance, meat quality, and antioxidation in male broilers. Poult. Sci. 2007, 86, 1356-1362. [CrossRef] [PubMed]

146. Lv, Z.P.; Yan, S.J.; Li, G.; Liu, D.; Guo, Y.M. Genistein improves the reproductive performance and bone status of breeder hens during the late egg-laying period. Poult. Sci. 2019, 98, 7022-7029. [CrossRef] [PubMed]

147. Azzam, M.M.; Jiang, S.Q.; Chen, J.L.; Lin, X.J.; Gou, Z.Y.; Fan, Q.L.; Wang, Y.B.; Li, L.; Jiang, Z.Y. Effect of soybean isoflavones on growth performance, immune function, and viral protein $5 \mathrm{mrna}$ expression in broiler chickens challenged with infectious bursal disease virus. Animals 2019, 9, 247. [CrossRef]

148. Lombardo, E.; Maraver, A.; Espinosa, I.; Fernández-Arias, A.; Rodriguez, J.F. VP5, the nonstructural polypeptide of infectious bursal disease virus, accumulates within the host plasma membrane and induces cell lysis. Virology 2000, 277, 345-357. [CrossRef]

149. Jackson, R.L.; Lin, H.Y.; Mao, J.T.S.; Chan, L.; Means, A.R. Estrogen induction of plasma vitellogenin in the cockerel: Studies with a phosvitin antibody. Endocrinology 1977, 101, 849-857. [CrossRef]

150. Kanuck, M.P.; Ellsworth, J.L. Tyrosine kinase inhibitors potentiate the induction of low density lipoprotein receptor gene expression by hepatocyte growth factor. Life Sci. 1995, 57, 1981-1991. [CrossRef]

151. Zhou, C.; Lin, H.; Ge, X.; Niu, J.; Wang, J.; Wang, Y.; Huang, Z.; Yu, W.; Tan, X. The Effects of dietary soybean isoflavones on growth, innate immune responses, hepatic antioxidant abilities and disease resistance of juvenile golden pompano Trachinotus ovatus. Fish Shellfish Immunol. 2015, 43, 158-166. [CrossRef]

152. Mai, K.; Zhang, Y.; Chen, W.; Xu, W.; Ai, Q.; Zhang, W. Effects of dietary soy isoflavones on feed intake, growth performance and digestibility in juvenile Japanese flounder (Paralichthys olivaceus). J. Ocean Univ. China 2012, 11, 511-516. [CrossRef]

153. Ko, K.; Malison, J.A.; Reed, J.D. Effect of Genistein on the growth and reproductive function of male and female yellow perch Perca flavescens. J. World Aquac. Soc. 1999, 30, 73-79. [CrossRef]

154. Gu, M.; Gu, J.N.; Penn, M.; Bakke, A.M.; Lein, I. Krogdahl Effects of diet supplementation of soya-saponins, isoflavones and phytosterols on Atlantic salmon (Salmo salar L.) fry fed from start-feeding. Aquac. Nutr. 2015, 21, 604-613. [CrossRef]

155. Pollack, S.J.; Ottinger, M.A.; Sullivan, C.V.; Woods, L.C. The Effects of the Soy Isoflavone Genistein on the Reproductive Development of Striped Bass. N. Am. J. Aquac. 2003, 65, 226-234. [CrossRef]

156. Power, D.M.; Llewellyn, L.; Faustino, M.; Nowell, M.A.; Björnsson, B.T.; Einarsdottir, I.E.; Canario, A.V.M.; Sweeney, G.E. Thyroid hormones in growth and development of fish. Comp. Biochem. Physiol. C Toxicol. Pharmacol. 2001, 130, 447-459. [CrossRef]

157. Chao, W.X.; Mei, J.; Wood, C.M. Effect of soy proteins and isoflavones on lipid metabolism and involved gene expression. Front. Biosci. 2008, 13, 2660-2673. [CrossRef]

158. Kataoka, J.; Mattox, J.R.; Quinn, J.; Kubo, H.; Makino, F.; Takahashi, T.; Inoue, S.; Hartman, R.C.; Madejski, G.M.; Sreekumar, P.; et al. Partial or total replacement of fish meal by soybean protein on growth, protein utilization, potential estrogenic or antigenic effects, cholesterolemia and flesh quality in rainbow trout, Oncorhynchus mykiss. Aquaculture 1995, 113, 737-740. [CrossRef]

159. Rzepkowska, M.; Roszko, M.Ł.; Fajkowska, M.; Adamek-Urbańska, D.; Ostaszewska, T. Dietary isoflavone intake and tissue concentration in cultured sturgeons. Aquac. Nutr. 2020, 26, 866-875. [CrossRef]

160. Fajkowska, M.; Rzepkowska, M.; Adamek, D.; Ostaszewska, T.; Szczepkowski, M. Expression of dmrt1 and vtg genes during gonad formation, differentiation and early maturation in cultured Russian sturgeon Acipenser gueldenstaedtii. J. Fish Biol. 2016, 89, 1441-1449. [CrossRef]

161. Pelissero, C.; Flouriot, G.; Foucher, J.L.; Bennetau, B.; Dunoguès, J.; Le Gac, F.; Sumpter, J.P. Vitellogenin synthesis in cultured hepatocytes. J. Steroid Biochem. Mol. Biol. 1993, 44, 263-272. [CrossRef]

162. Pelissero, C.; Bennetau, B.; Babin, P.; Le Menn, F.; Dunogues, J. The estrogenic activity of certain phytoestrogens in the siberian sturgeon Acipenser baeri. J. Steroid Biochem. Mol. Biol. 1991, 38, 293-299. [CrossRef]

163. Ng, Y.; Hanson, S.; Malison, J.A.; Wentworth, B.; Barry, T.P. Genistein and other isoflavones found in soybeans inhibit estrogen metabolism in salmonid fish. Aquaculture 2006, 254, 658-665. [CrossRef] 
164. Botta, B.; Menendez, P.; Zappia, G.; de Lima, R.; Torge, R.; Monache, G. Prenylated Isoflavonoids: Botanical Distribution, Structures, Biological Activities and Biotechnological Studies. An Update (1995-2006). Curr. Med. Chem. 2009, 16, $3414-3468$. [CrossRef]

165. Wang, H.J.; Murphy, P.A. Isoflavone Composition of American and Japanese Soybeans in Iowa: Effects of Variety, Crop Year, and Location. J. Agric. Food Chem. 1994, 42, 1674-1677. [CrossRef]

166. D'Mello, J.P.F.; Placinta, C.M.; Macdonald, A.M.C. Fusarium mycotoxins: A review of global implications for animal health, welfare and productivity. Anim. Feed Sci. Technol. 1999, 80, 183-205. [CrossRef]

167. Gruber-Dorninger, C.; Jenkins, T.; Schatzmayr, G. Global mycotoxin occurrence in feed: A ten-year survey. Toxins 2019, 11, 375. [CrossRef]

168. Palumbo, R.; Crisci, A.; Venâncio, A.; Abrahantes, J.C.; Dorne, J.L.; Battilani, P.; Toscano, P. Occurrence and co-occurrence of mycotoxins in cereal-based feed and food. Microorganisms 2020, 8, 74. [CrossRef]

169. Mustonen, E.; Tuori, M.; Kurki, P.; Isolahti, M.; Taponen, J.; Vanhatalo, A. Variety, time of harvest and conditions during growing season have impact on red clover isoflavone content. Agric. Food Sci. 2018, 27, 102-109. [CrossRef]

170. Penagos-tabares, F.; Khiaosa-ard, R.; Nagl, V.; Faas, J.; Jenkins, T.; Sulyok, M.; Zebeli, Q. Mycotoxins, Phytoestrogens and Other Secondary Metabolites in Austrian Pastures: Occurrences, Contamination Levels and Implications of Geo-Climatic Factors. Toxins 2021, 13, 460. [CrossRef]

171. Hu, X.; Hu, R.; Zhang, Z.; Li, P.; Zhang, Q.; Wang, M. Development of a multiple immunoaffinity column for simultaneous determination of multiple mycotoxins in feeds using UPLC-MS/MS. Anal. Bioanal. Chem. 2016, 408, 6027-6036. [CrossRef]

172. Pietsch, C.; Kersten, S.; Burkhardt-Holm, P.; Valenta, H.; Dänicke, S. Occurrence of deoxynivalenol and zearalenone in commercial fish feed: An initial study. Toxins 2013, 5, 184-192. [CrossRef]

173. Lee, M.J.; Kim, H.J. Development of an immunoaffinity chromatography and LC-MS/MS method for the determination of 6 zearalenones in animal feed. PLoS ONE 2018, 13, e0193584. [CrossRef]

174. Romera, D.; Mateo, E.M.; Mateo-Castro, R.; Gómez, J.V.; Gimeno-Adelantado, J.V.; Jiménez, M. Determination of multiple mycotoxins in feedstuffs by combined use of UPLC-MS/MS and UPLC-QTOF-MS. Food Chem. 2018, 267, 140-148. [CrossRef] [PubMed]

175. Tima, H.; Rácz, A.; Guld, Z.; Mohácsi-Farkas, C.; Kiskó, G. Deoxynivalenol, zearalenone and T-2 in grain based swine feed in Hungary. Food Addit. Contam. Part B Surveill. 2016, 9, 275-280. [CrossRef] [PubMed]

176. Kongkapan, J.; Poapolathep, S.; Isariyodom, S.; Kumagai, S.; Poapolathep, A. Simultaneous detection of multiple mycotoxins in broiler feeds using a liquid chromatography tandem-mass spectrometry. J. Vet. Med. Sci. 2016, 78, 259-265. [CrossRef] [PubMed]

177. Kosicki, R.; Błajet-Kosicka, A.; Grajewski, J.; Twaruzek, M. Multiannual mycotoxin survey in feed materials and feedingstuffs. Anim. Feed Sci. Technol. 2016, 215, 165-180. [CrossRef]

178. Wu, L.; Li, J.; Li, Y.; Li, T.; He, Q.; Tang, Y.; Liu, H.; Su, Y.; Yin, Y.; Liao, P. Aflatoxin B1, zearalenone and deoxynivalenol in feed ingredients and complete feed from different Province in China. J. Anim. Sci. Biotechnol. 2016, 7, 1-10. [CrossRef]

179. Czembor, E.; Stępień, Ł.; Waśkiewicz, A. Effect of environmental factors on Fusarium species and associated mycotoxins in maize grain grown in Poland. PLoS ONE 2015, 10, e0133644. [CrossRef]

180. Ma, R.; Zhang, L.; Liu, M.; Su, Y.T.; Xie, W.M.; Zhang, N.Y.; Dai, J.F.; Wang, Y.; Rajput, S.A.; Qi, D.S.; et al. Individual and combined occurrence of mycotoxins in feed ingredients and complete feeds in China. Toxins 2018, 10, 113. [CrossRef]

181. Li, X.; Zhao, L.; Fan, Y.; Jia, Y.; Sun, L.; Ma, S.; Ji, C.; Ma, Q.; Zhang, J. Occurrence of mycotoxins in feed ingredients and complete feeds obtained from the Beijing region of China. J. Anim. Sci. Biotechnol. 2014, 5, 37. [CrossRef]

182. Kovalsky, P.; Kos, G.; Nährer, K.; Schwab, C.; Jenkins, T.; Schatzmayr, G.; Sulyok, M.; Krska, R. Co-occurrence of regulated, masked and emerging mycotoxins and secondary metabolites in finished feed and maize-An extensive survey. Toxins 2016, 8 , 363. [CrossRef]

183. Lee, M.; Seo, D.J.; Jeon, S.B.; Ok, H.E.; Jung, H.; Choi, C.; Chun, H.S. Detection of foodborne pathogens and mycotoxins in eggs and chicken feeds from farms to retail markets. Korean J. Food Sci. Anim. Resour. 2016, 36, 463-468. [CrossRef]

184. Changwa, R.; Abia, W.; Msagati, T.; Nyoni, H.; Ndleve, K.; Njobeh, P. Multi-mycotoxin occurrence in dairy cattle feeds from the gauteng province of South Africa: A pilot study using UHPLC-QTOF-MS/MS. Toxins 2018, 10, 294. [CrossRef]

185. Bernhoft, A.; Christensen, E.; Morten, S. Surveillance Programmes for Terrestrial and Aquatic Animals in Norway. The Surveillance Programme for Enzootic Bovine Leukosis (EBL) in Norway 2015; Norwegian Veterinary Institute: Oslo, Norway, 2015.

186. Abdallah, M.F.; Girgin, G.; Baydar, T.; Rudolf, K.; Sulyok, M. Occurrence of multiple mycotoxins and other fungal metabolites in animal feed and maize samples from Egypt using LC-MS/MS. Sci. Food Agric. 2017, 97, 4419-4428. [CrossRef]

187. Gruber-Dorninger, C.; Jenkins, T.; Schatzmayr, G. Multi-mycotoxin screening of feed and feed raw materials from Africa. World Mycotoxin J. 2018, 11, 369-383. [CrossRef]

188. Calori-Domingues, M.A.; Iwahashi, P.M.R.; Ponce, G.H.; Gloria, E.M.; Dias, C.T.; Button, D.C.; De Camargo, A.C. Aflatoxin B1 and zearalenone in soybeans: Occurrence and distribution in whole and defective kernels. Food Addit. Contam. 2018, 11, 273-280. [CrossRef]

189. Iqbal, S.Z.; Asi, M.R.; Nisar, S.; Zia, K.M.; Jinap, S.; Malik, N. A limited survey of aflatoxins and zearalenone in feed and feed ingredients from Pakistan. J. Food Prot. 2016, 79, 1798-1801. [CrossRef]

190. Chang, H.; Kim, W.; Park, J.H.; Kim, D.; Kim, C.R.; Chung, S.; Lee, C. The occurrence of zearalenone in south korean feedstuffs between 2009 and 2016. Toxins 2017, 9, 223. [CrossRef] 
191. Daems, F.; Romnee, J.M.; Rasse, C.; Froidmont, É; Heuskin, S.; Lognay, G. Quantification of Four Isoflavones in Forages with $\mathrm{UPLC}^{\circledR}$-MS/MS, Using the Box-Behnken Experimental Design to Optimize Sample Preparation. Chromatographia 2016, 79, 711-725. [CrossRef]

192. Sulyok, M.; Stadler, D.; Steiner, D.; Krska, R. Validation of an LC-MS/MS-based dilute-and-shoot approach for the quantification of $>500$ mycotoxins and other secondary metabolites in food crops: Challenges and solutions. Anal. Bioanal. Chem. 2020, 412, 2607-2620. [CrossRef]

193. McNutt, S.H.; Purwin, P.; Murray, C. Vulvovaginitis in swine. J. Am. Vet. Med. Assoc. 1928, 73, 1928. 